Article

\title{
Environmental Life Cycle Assessment of Grid-Integrated Hybrid Renewable Energy Systems in Northern Nigeria
}

\author{
Ismail Abubakar Jumare ${ }^{1,2, *(\mathbb{C})}$, Ramchandra Bhandari ${ }^{3}$ ab and Abdellatif Zerga ${ }^{2}$ \\ 1 Mechanical Engineering Department, Faculty of Technology, University of Tlemcen, \\ B.P. 119 | Pôle Chetouane, Tlemcen 13000, Algeria \\ 2 Pan African University Institute of Water and Energy Sciences-PAUWES, c/o University of Tlemcen, \\ B.P. 119 | Pôle Chetouane, Tlemcen 13000, Algeria; abdellatif.zerga@gmail.com \\ 3 Institute for Technology and Resources Management in the Tropics and Subtropics, TH Köln-University of \\ Applied Sciences, Betzdorfer Strasse 2, 50679 Cologne, Germany; ramchandra.bhandari@th-koeln.de \\ * Correspondence: shehius61@yahoo.com; Tel.: +213(0)673814728
}

Received: 18 September 2019; Accepted: 18 October 2019; Published: 23 October 2019

check for updates

\begin{abstract}
Life cycle assessment is a crucial tool in evaluating systems performances for sustainability and decision-making. This paper provided environmental impact of integrating renewable energy systems to the utility-grid based on a baseline optimized energy production data from "HOMER" for renewable systems modelling of a site in northern Nigeria. The ultimate goal was to ascertain the best hybrid option(s) in sustaining the environment. Different assumptions and scenarios were modelled and simulated using Ganzleitlichen Bilanz $(\mathrm{GaBi})$. Uncertainty analysis was ensured to the impact data based on pedigree-matrix and Excel-program, as well as overall policy relevance. The results of the impact categories revealed first scenario (i.e., conventional path-based) with the highest impacts on global warming potential (GWP), acidification potential (AP), human toxicity potential (HTP), and abiotic depletion potential $\left(\mathrm{ADP}_{\text {fossiss }}\right)$. The lowest impacts arise in the renewable-based scenarios for all the considered categories except the Ozone-layer depletion potential Category where the highest contribution falls in the third scenario (i.e., photovoltaic (PV)/biomass-biogas system) although all values being infinitesimal. In quantitative terms, the reduction in the GWP from the highest being the first scenario to the lowest being the fourth scenario (i.e., wind/biomass-biogas system) was $96.5 \%$. Hence, with the outstanding contributions of the hybrid renewable systems, adopting them especially the lowest impact scenarios with expansions is relevant for environmental sustainability.
\end{abstract}

Keywords: hybrid renewable energy system; grid-integration; life cycle assessment; environmental; uncertainty analyses; policy relevance

\section{Introduction}

Energy production and utilization are strongly necessary for development, and are considered as key indicators to industrialization. The kind of energy services to pursue has a strong impact on sustainable development. Therefore, by definition, sustainable development is an improvement that fulfils the need of the present, as well as the future generation without compromising their ability [1]. The sustainable development fundamentally covered three pillars, that is social, economic and environmental pillars. The environmental concerns in this regard are being focused on, as the research was solely based them. It is evident that the global population continues to rise drastically, ultimately leading to drastic increase in energy demand, which requires energy supply and ensuring a sustainable environment for socio-economic development at all levels [2]. It is strongly noted that 
human survival and their living standard level strongly depend on their environment either directly or indirectly. Hence it is obvious as to how the three pillars are strongly intertwined.

In ascertaining the full sustainable impact of a system or a product, life cycle assessment (LCA) is a key. Therefore, LCA basically entails holistic evaluations of a material, product, process, or service on its environmental impacts over its whole life cycle, that is from cradle to death [3]. There are fundamentally two basic approaches to the LCA, that is attributional, describing the physical flows to and from the LCA system, and the consequential approach describing the environmental consequences of possible future altering of physical flows from and to an LCA system [4]. Different stages are thus necessary in realizing the LCA, namely the goal and scope definition, inventory analyses, impact assessment and overall interpretations in accordance with the ISO 14040 [5]. On the basis of the brief description, many software packages with extensive databases comprising of inventory data sets in a wide range of areas necessary and sufficient for conducting any LCA have been developed. The Environmental Protection Agency (EPA) has identified and vividly described around 25 software packages each having different features but similar concepts; however, the most commonly used ones are the Ganzheitliche Bilanz (GaBi), System for Integrated Environmental Assessment of Products (SIMAPRO), Umberto LCA+, and openLCA $[3,6]$. In addition, LCA approach has been reported according to the works by Kelly and Bruijn et al. [3,7] to be applied in different domains; namely, research and industrial measures, complex business strategies, policy environment, and specifically for products, services and behavioral life style choices.

On the basis of the literature search, it was observed that many research works have been conducted and published in the field of LCA in the global context, including the domain of renewable energy. Bringing in some of the studies while restricting to only the renewable energy-based is necessary in ascertaining the uniqueness of this research contribution. Luo et al. [8] conducted a comparative life cycle assessment of photovoltaics electricity generation by different multi-crystalline silicon technologies applied in Singapore. The study was on the basis of energy payback periods and greenhouse gas emissions. A regional life cycle assessment for sustainability of solar photovoltaics in the north east of England has been addressed by Li et al. [9]. The study focused on three categories or indicators namely the techno-economic, environmental, and social impacts. Liptow et al. [10] accounted for the effect of carbon flows in LCA of biomass-based products considering the case of Sweden for wood to ethylene and Brazil for sugarcane to ethylene via different routes. The global warming potentials and land use impacts were the analyzed indicators in the life-cycle. Jones et al. [11] applied the benefits and limitations qualitative measures to a prospective and consequential LCA and net energy analyses (NEA) of decentralized electricity generation. They concluded that a combined LCA and NEA approach are appropriate, provided a number of policy related issues are addressed. A comparative study of the environmental life cycle impacts of nuclear, wind, and hydropower plants in Ontario, Canada has been conducted by Siddiqui and Dincer [12]. The study was done using GaBi tool, with the LCIA Method of the Institute of Environmental Sciences of the University of Leiden (CML) 2015 considered and different life cycle impact categories analyzed. Uddin and Kumar [13] compared the performance of vertical and horizontal wind turbine in Thailand on an LCA basis using SimaPro. The approach considered involved analyzing the LCA embodied energy, as well as environmental and emission impacts.

Additionally, Atilgan and Azapagic [14] worked on the life cycle environmental impacts for renewable electricity in Turkey. Different power plants were considered in the country both large and small, and ranging from hydropower to wind and to geothermal in different locations. The analyses were conducted using GaBi tool via a CML 2001 approach and the impact categories were evaluated. Rajput et al. [15] carried out an LCA of $3.2 \mathrm{~kW}$ cadmium telluride PV system in India. The study approach was based on energy performance and costing, where parameters such as energy payback period, energy production factor, life cycle conversion efficiency, and life cycle cost were analyzed. Santoyo-Castelazo and Azapagic [16] offered a sustainability assessment of energy systems of different scenarios in the future energy supply of Mexico. The approaches put forward in the study 
were environmental LCA and life cycle costs (LCC), social sustainability and multi-criteria decision analyses. Life cycle assessment of substituting natural gas for biofuels in industrial heat generation was studied by Repele and Bazbauers [17] in Latvia. Different biofuels where considered in the substitution including biogas, first- and second-generation biofuels with the environmental impacts analyzed using SimaPro based on Recipe and EcoIndicator 99 approaches. To proceed further, Menoufi et al. [18] proposed a life cycle assessment in comparing building added concentrated photovoltaics (BACPV) and conventional building integrated photovoltaics (BIPV) system in Spain. The authors applied the energy performance measures namely energy payback and energy return factor, coupled with the environmental impact indicators.

Basing on the reviewed studies on hybrid-based systems, Ristimaki et al. [19] made their investigations on LCA for a new residential district energy system in Finland. The approach employed involved linking the life cycle carbon emission with life cycle costing, with different systems such as heating and electricity including hybrid and renewables incorporation considered. Ayodele et al. [2] conducted a life cycle assessment of waste to energy technologies for electricity generation in Nigeria. Different scenarios that include hybrids were considered in the study for the waste processing techniques, with the analytical approach being electricity generation potentials and environmental impacts. Additionally, the life cycle assessment and life cycle costing analyses have been addressed by Petrillo et al. [20], for an off-grid hybrid renewable energy system in Egypt. The authors considered different scenarios both singly and in hybrid using reciprocating diesel engine, solar PV, and fuel cell based on the Eco-indicator 99 method. Wang et al. [21] conducted a study on the life cycle analyses optimization of a solar-aided hybrid trigeneration system (i.e., combined cooling, heating and power (CCHP)) in Beijing, China. The hybrid consisted of grid-connected solar PV and natural gas power plants with additional solar thermal systems for the energy demand side of the site. The optimization approach was on configuration and load operation variability in minimizing the environmental impact. The summary of all the reviewed studies have been provided in Table 1 at the end of the section.

Table 1. Summary of the studies consulted in comparison to the study in this paper. [CCHP, combined cooling, heating, and power; PV, photovoltaics; BACPV, building added concentrated PV; BIPV, conventional building integrated PV; GaBi, Ganzheitliche Bilanz; NEA, net energy analyses; AP, acidification potential; BAU, business as usual; $\mathrm{CdTe}$, cadmium telluride].

\begin{tabular}{|c|c|c|}
\hline Reference & Location/Year & $\begin{array}{c}\text { Main Content (Research Approach and } \\
\text { Observation) }\end{array}$ \\
\hline Luo et al. [8] & Singapore/2018 & $\begin{array}{l}\text { Life cycle energy performance and } \\
\text { greenhouse gas (GHG) emission analyses } \\
\text { approach for PV generations } \\
\text { (multi-crystalline technologies). Passivated } \\
\text { Emitter and Rear Cell (PERC) solar cells } \\
\text { with frameless double glass-module was } \\
\text { observed with lowest energy payback and } \\
\text { GHG emission in the scope of materials } \\
\text { considered. }\end{array}$ \\
\hline Li et al. [9] & North East of England/2017 & $\begin{array}{l}\text { Full sustainability impacts assessment on } \\
\text { life cycle assessment (LCA) ground for solar } \\
\text { PV. Solar availability was proved to have } \\
\text { direct impact on the sustainability pillars } \\
\text { however, the costs implications required } \\
\text { proper policy shaping in its favor. }\end{array}$ \\
\hline Liptow et al. [10] & Sweden \& Brazil/2018 & $\begin{array}{l}\text { Global Warming Potential (GWP) and land } \\
\text { use impact evaluations for biomass-based } \\
\text { products. Land use impacts were observed } \\
\text { to have a profound effect on the GWP. }\end{array}$ \\
\hline
\end{tabular}


Table 1. Cont.

\begin{tabular}{|c|c|c|}
\hline Reference & Location/Year & $\begin{array}{c}\text { Main Content (Research Approach and } \\
\text { Observation) }\end{array}$ \\
\hline Jones et al. [11] & 2017 & $\begin{array}{l}\text { Benefits and limitations qualitative } \\
\text { approach for consequential LCA and NEA } \\
\text { of decentralized power. It was ascertained } \\
\text { that the combined LCA and NEA approach } \\
\text { is appropriate, provided a number of policy } \\
\text { related issues are addressed }\end{array}$ \\
\hline
\end{tabular}

Siddiqui \& Dincer [12]

Ontario, Canada/2017

Atilgan \& Azapagic [14]

Turkey/2016

Rajput et al. [15]

India/2018

Santoyo-Castelazo and Azapagic [16]

Mexico/2014

Repele and Bazbauers [17]

Latvia/2015

Menoufi et al. [18]

Spain/2017

Ristimari et al. [19]

Finland/2013
CML 2015 LCA based approach with GaBi employed for nuclear, wind \& hydro, with different environmental impact indicators analyzed. Sensitivity analyses covered on recycle rates. Hydro had the least GWP. Increased recycling rate lowered the environmental Impacts

Energy and environmental impact performance based LCA approach for wind technologies using SimaPro. The vertical axis turbine was found to be energy and emission intensive.

GaBi tool-based analyses based on CML 2001 approach for different renewable power plants. Many environmental impact categories analyzed. Impacts from large hydropower were observed to be lower than from small hydropower. Other observations were provided in the study.

Energy performance and costs-based LCA approach for a PV CdTe PV technology. The embodied energy and the energy payback were observed to be low as compared with c-Si PV technology.

Environmental LCA and life cycle cost (LCC), social sustainability and multi-criteria decision analyses were the approach for the sustainability of different future energy supply. It was observed that BAU fossils are not sustainable regardless of the criteria preference. Higher renewable and nuclear penetration are the most suitable in meeting the low carbon future target.

Recipe and EcoIndicator "99" environmental-based LCA approaches were employed for biofuels to heat system. High impact reduction was observed especially for biogas and second-generation biofuels from natural gas utilization.

Energy performance measures and environmental indicators were applied for LCA of BIPV and BACPV technologies. It was observed that the BACPV has a lower environmental impact than the BIPV. BACPV has lower energy payback and higher energy return factor than BIPV.

Different energy systems i.e., heat and power with hybrid-based LCA were done by life cycle carbon emission and the LCC approach. It was observed that the system with the highest initial cost is the most viable on life cycle ground. 
Table 1. Cont.

\begin{tabular}{|c|c|c|}
\hline Reference & Location/Year & $\begin{array}{c}\text { Main Content (Research Approach and } \\
\text { Observation) }\end{array}$ \\
\hline Ayodele et al. [2] & Nigeria/2017 & $\begin{array}{l}\text { Electricity generation potential and } \\
\text { environmental impact based LCA approach } \\
\text { for waste to energy technologies including } \\
\text { hybrids (power) addressed. Some of the } \\
\text { observations show the } \\
\text { Incineration/Anaerobic Digestion is more } \\
\text { viable in terms of GWP and AP. }\end{array}$ \\
\hline Petrillo et al. [20] & Egypt/2016 & $\begin{array}{l}\text { Environmental LCA and LCC based on } \\
\text { EcoIndicator "99" were addressed for } \\
\text { off-grid renewable power systems both } \\
\text { singly and in hybrids. }\end{array}$ \\
\hline Wang et al. [21] & Beijing, China/2015 & $\begin{array}{l}\text { LCA optimization was conducted on the } \\
\text { solar-aided trigeneration system. The } \\
\text { optimization approach was based on } \\
\text { configuration and load operational } \\
\text { variability for environmental impact } \\
\text { minimization. It was observed that } \\
\text { minimizing the total environmental impact } \\
\text { potential for non-benefit case i.e., benefit } \\
\text { surplus products excluded from CCHP, } \\
\text { following an electric load is the objective } \\
\text { with the lowest environmental impacts. }\end{array}$ \\
\hline \multicolumn{3}{|l|}{ This paper/study } \\
\hline Jumare et al. & Zaria, Nigeria & $\begin{array}{l}\text { Different hybrid power system } \\
\text { environmental impact evaluations (PV, } \\
\text { Wind, Biomass, and Conventional systems). } \\
\text { Linkage to HOMER software optimization } \\
\text { results for models building. uncertainty } \\
\text { analyses for impact data as a quality } \\
\text { measure. Policy linkage for decision } \\
\text { makers. }\end{array}$ \\
\hline
\end{tabular}

Having seen some of the past works in the research domain, focusing the argument on the African context, and specifically on Nigeria, the dominance of conventional energy sources is obvious specifically the fossil fuels in the electricity mix with less or no diversification to clean energy services. The overdependence on the fossil energy has been proved by many researchers to have potential detrimental impact to the environment. Hence, the need to diversify sources with clean energy, while lowering the fossil fuel uptake level for their ability to last a long time. This is in view of the depleting nature of fossil energy resources.

Therefore, the purpose of this paper was to see the environmental impact on life cycle ground, for grid-integration of hybrid renewable energy systems into an existing grid in the Nigerian context, focusing on a specific site in the northern part. This was with an ultimate goal of observing the best hybrid option(s) in sustaining the environment based on least impacts. That was achieved based on different model scenarios with different assumptions analyzed, uncertainty evaluation addressed and a wrap-up policy relevance assessment. The renewable energy systems covered were solar PV, wind turbine, and biomass-biogas systems on the baseline of HOMER optimization results. The novelty of this paper is on the strong linkage to HOMER tool energy system modelling, and the uniqueness of the different hybrid systems considered especially in the case study country where such aspects have not been addressed so far. On a final note, the motivation behind the study was generally on the need to address natural resources depletion as well as environmental degradation in making a proper decision as to what is appropriate and sustainable for the environment.

The manuscript is structured in sections following the introduction as follows: The study site is clearly described in Section 2. Section 3 deals with the adopted research methods in much details with an accompanied summarized block diagram of the different deliverables. The results and discussion, 
covering the elementary mass balance, the different environmental impact categories, the uncertainty evaluations, and overall policy relevance has been addressed in Section 5. Lastly, the conclusion comes in Section 5.

As a final point, the limitation of the research lies in the solely environmental impact analyses without any economic impact or life cycle costing evaluations in the study site. This is therefore strongly recommended as a future work in line with this study. A further limitation stems on the nature of the data collected in the modelling, which were mostly of broader applications beyond the study site. However, this limitation was addressed in the pedigree matrix uncertainty analyses conducted.

\section{Study Site Description}

Nigeria is a country blessed with abundant fossil fuel resources, specifically oil and natural gas. It is ranked as the leading country in terms of the natural gas reserve, and is second after Libya in oil reserve in the African continent. It must be stated also that abundant renewable energy resources exist in the country namely biomass, wind, solar, and hydro although being site specific. It is unfortunate that the level of utilization of the renewable sources to final energy generation is chronically poor. Instead, overdependence on fossil resources for final energy services particularly electricity as our central focus has been a habitual thing despite their depleting nature and some environmental consequences. In this context as a strong view, integrating the renewable energy resources is very crucial in line with the low carbon development transition target, and most significantly for the environmental concerns. This study focusing on the northern part of the country is driven by the existence of high potential for climate-data related renewable energy resources namely the solar irradiation and wind speed. The other resource of interest namely the biomass in the form of waste is considered to be virtually everywhere and in abundance in the whole country. It is considered a resource in disguise, and needs to be utilized in an efficient manner for environmental benefits. Moving specifically to the study location in the northern part of the country, Zaria, it is a municipal area with Coordinate $11.085^{\circ} \mathrm{N}$ and $7.72^{\circ} \mathrm{E}$. The site is situated on a plateau at an elevation of $670 \mathrm{~m}$ above sea level [22], and has a total area of $563 \mathrm{~km}^{2}$ with a population of about 975,200 during 2015 [23]. The site's climate is tropical wet and dry caused by movement of the inter-tropical discontinuity under two air mass influences, that is tropical continental and tropical maritime [24]. To specify further the tropical wet and dry climate nature, the wet season (i.e., summer) lasts from April to October whereas, the dry season (i.e., winter) lasts from November to March. Figures 1 and 2 give the climate-based data, that is solar and wind resources. This is accompanied by the biomass broad classification in Figure 3, as well as the specific biogas resources, that is the animal wastes quantification considered for the biogas fuel production applicable to power generations in Table 2. These are fundamental in modelling the power generations useful for analyzing the environmental life cycle impact.

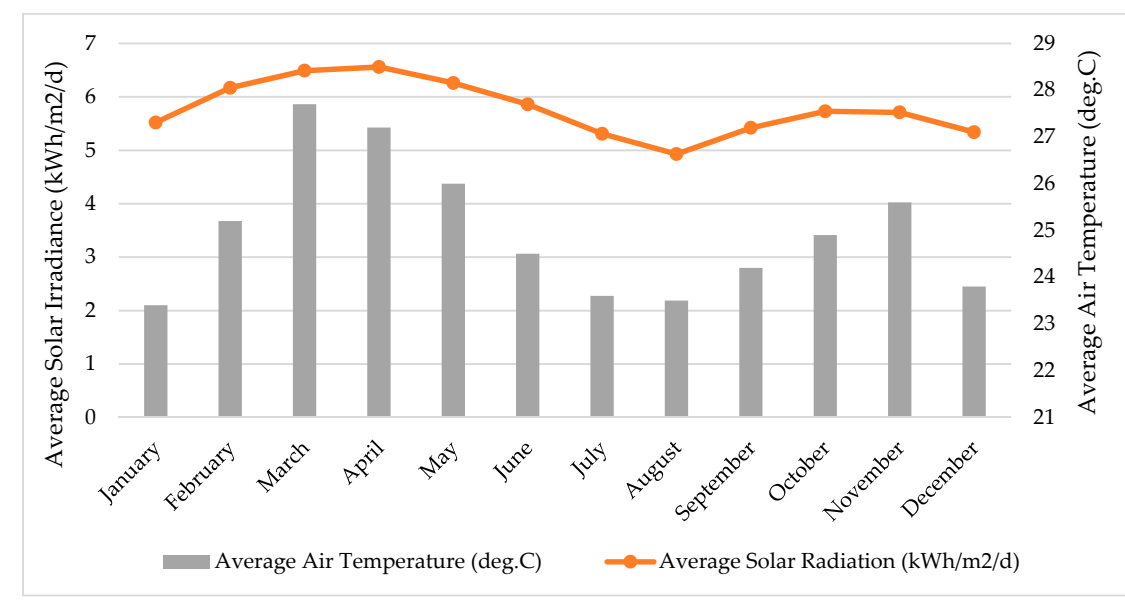

Figure 1. Average monthly solar irradiation and air temperature for the site of Zaria, Nigeria [25]. 


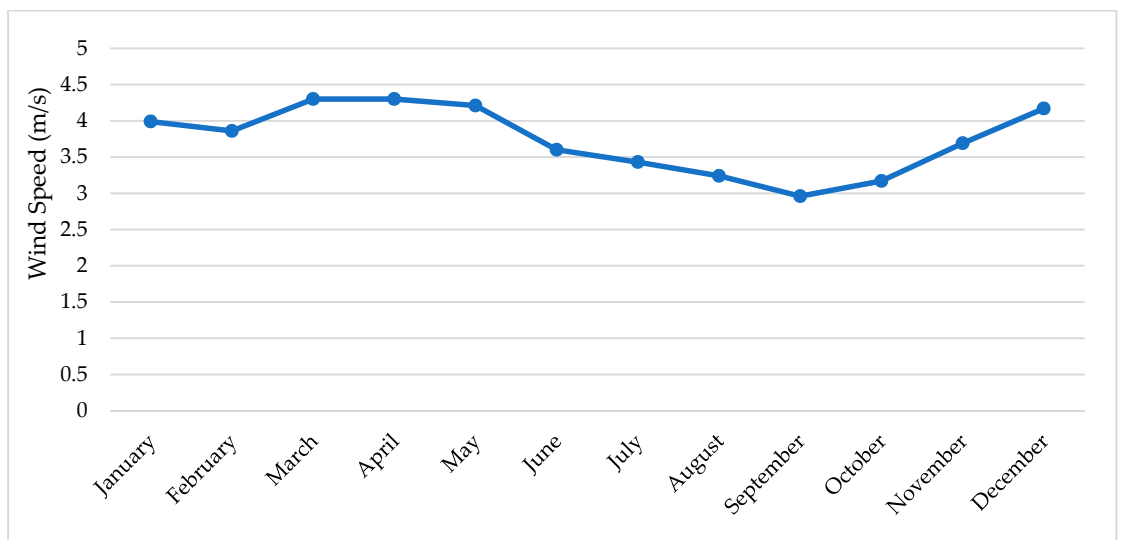

Figure 2. Average monthly wind speed for the site of Zaria, Nigeria at $50 \mathrm{~m}$ [25].

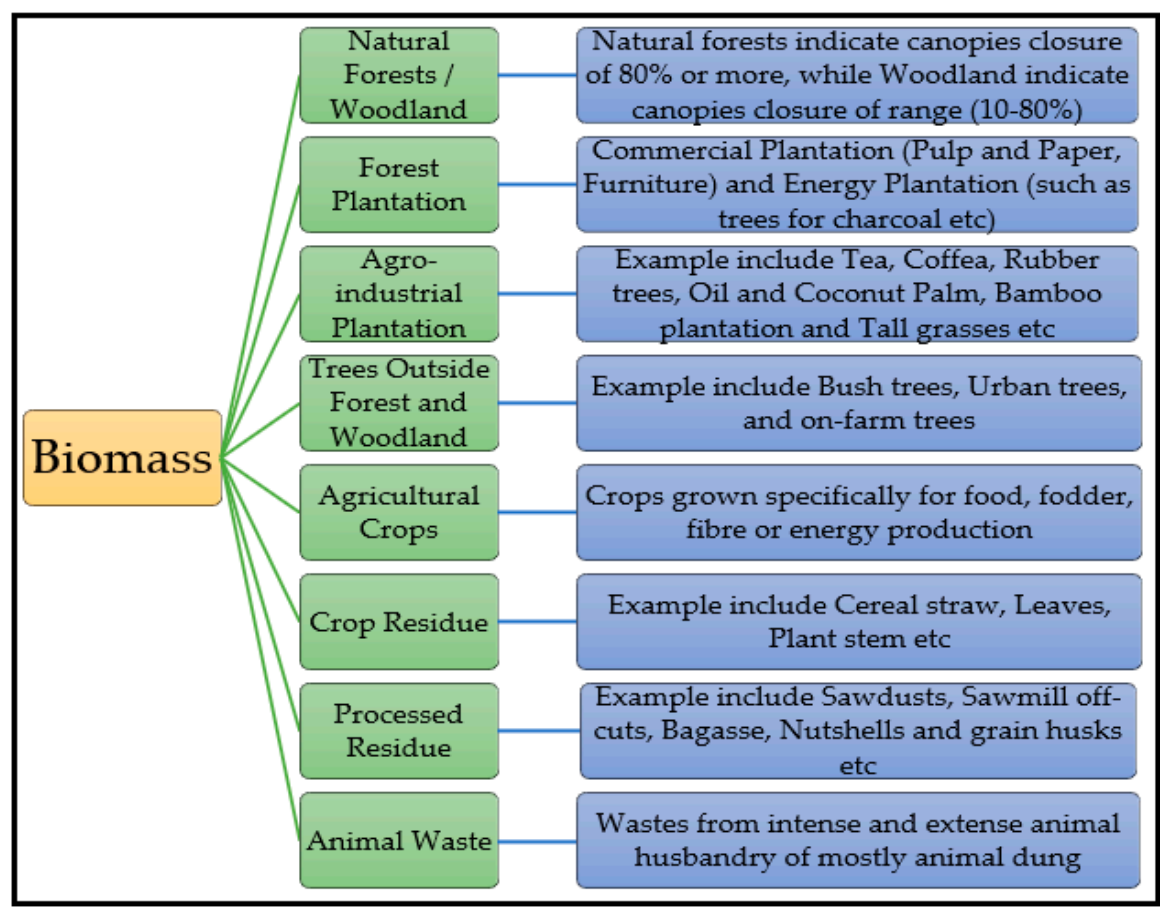

Figure 3. Biomass resource broad classification with specifications [26].

Table 2. Nigerian cumulative biomass production and the analyzed values on average for the site of Zaria in 2014 (animal wastes) [27-31].

\begin{tabular}{|c|c|c|c|c|c|c|c|}
\hline Item & $\begin{array}{c}\text { National } \\
\text { Production } \\
\text { (Million } \\
\text { Heads) }\end{array}$ & $\begin{array}{l}\text { Site } \\
\text { Production } \\
\text { on Average } \\
\text { (Thousand } \\
\text { Heads) }\end{array}$ & $\begin{array}{l}\text { Dry matter } \\
\text { Production } \\
(\mathrm{kg} / \text { Head/d) }\end{array}$ & $\begin{array}{c}\text { National dry } \\
\text { Matter } \\
\text { Production } \\
\text { (kg/yr.) }\end{array}$ & $\begin{array}{l}\text { Site's Dry } \\
\text { Matter } \\
\text { Production } \\
\text { on Average } \\
\text { (kg/yr.) }\end{array}$ & $\begin{array}{c}\text { Carbon } \\
\text { Content on } \\
\text { Average } \\
\text { (Ultimate } \\
\text { Analyses) }\end{array}$ & $\begin{array}{c}\text { Biogas } \\
\text { Potential } \\
\left(\mathrm{m}^{3} / \mathrm{kg} \&\right. \\
\mathrm{kg} / \mathrm{kg} \text { of Dry } \\
\text { Matter) }\end{array}$ \\
\hline Cattle & 19.54 & 22.97 & 2.860 & $2.04 \times 10^{10}$ & $2.40 \times 10^{7}$ & $22.5 \%$ & $0.20 \& 0.24$ \\
\hline Goat & 72.47 & 85.16 & 0.552 & $1.46 \times 10^{10}$ & $1.72 \times 10^{7}$ & $29.5 \%$ & $0.25 \& 0.30$ \\
\hline Pig & 7.07 & 8.30 & 0.661 & $1.71 \times 10^{9}$ & $2.00 \times 10^{6}$ & $40.7 \%$ & $0.56 \& 0.67$ \\
\hline Sheep & 41.33 & 48.56 & 0.329 & $4.96 \times 10^{9}$ & $5.83 \times 10^{6}$ & $31.4 \%$ & $0.25 \& 0.30$ \\
\hline Chicken & 144.95 & 170.33 & 0.043 & $2.28 \times 10^{9}$ & $2.67 \times 10^{6}$ & $32.6 \%$ & $0.28 \& 0.34$ \\
\hline Horse & 0.11 & 0.13 & 3.3 & $1.30 \times 10^{8}$ & $1.54 \times 10^{5}$ & $41.5 \%$ & $0.30 \& 0.36$ \\
\hline Total & 285.46 & 335.45 & N/A & $2.04 \times 10^{10}$ & $5.22 \times 10^{7}$ & N/A & N/A \\
\hline
\end{tabular}




\section{Research Methodology}

The research methodology followed an exemplary life cycle stages based on the "ISO 14044". This standard defined in much details, the goal and scope, as well as the inventory analyses with its broad discussions, leading to the different LCA impact parameters evaluation.

\subsection{Goal and Scope Definition}

The ultimate goal of the research defined already in the introduction part was to investigate in details, the best hybrid option(s) for the grid integration in ascertaining environmental sustainability on a life cycle ground. This is in favor of better decision making in energy operations. The Functional Unit (FU) that defines the reference flow for the systems and models' comparison was scaled down to "unit kWh of electricity generation", with all the arguments in the analyses being based on this.

Regarding the scope, of all the different scenarios analyzed in the inventory part, the overall mass balance analysis for different elementary flows was looked in to, coupled with in-depth environmental impact categories evaluations based on the selected "LCIA-CML 2015 attributional-based approach". The selected impact categories within the limit of this research were the global warming potential (GWP), acidification potential (AP), Ozone-layer depletion potential (ODP), eutrophication potentials (EP), human toxicity potential (HTP), and abiotic depletion potential $\left(\mathrm{ADP}_{\text {fossils }}\right)$. The impact data uncertainty analysis was also incorporated. In all cases, the analyses have been on a cradle to grave basis. The different components or technologies in the scenarios were based on medium operational conditions for production in the mix, having being predicted by researchers to be the main world market. Regarding the system boundary, different materials and energy inputs and outputs were incorporated as the life cycle flows. These include agricultural-related materials, radioactive-based materials, water, organic-based materials, volatile organic compounds, halogenated materials, heavy metals, as well as all the necessary energy inputs and the electricity outputs of the different processes involved in the different models and so on. Lastly, an overall wrap-up policy relevance analysis was ensured.

\subsection{Inventory Analyses}

The inventory analyses for the research begin with the collection and analyses of the Nigerian electricity generation data of a given 2014 baseline year, which is $29,729 \mathrm{GWh}$, having a mix of $\sim 60 \%$ natural gas, $\sim 20 \%$ oil, and $\sim 20 \%$ hydropower as obtained from the work of [32]. However, the overall task was based on the optimization results of HOMER software for grid-connected solar PV, wind turbine, and biomass-gasified power components of the power system exercise done. This was based on the resource data obtained and other various input specifications and evaluations. Only the optimization results have been brought forth for the LCA analyses. The optimized results were in an attempt to supply energy to 200 households (1200 persons in total) in the considered site, with a peak load of $4 \mathrm{MW}$. The annual analyzed load profile for the site is shown Figure 4, and the optimization results summary in addressing the load demand as applicable to the environmental life cycle analyses is shown in Table 3.

Table 3. HOMER optimization results for the site as input to the LCA assessment.

\begin{tabular}{cc}
\hline Optimum Parameters & Specification \\
\hline Optimized configuration & PV system: $2000 \mathrm{~kW}$; wind turbine: 30 pieces \\
Energy production from solar PV subsystem & $(330 \mathrm{~kW}$ rated each); biogas system: $2500 \mathrm{~kW}$ \\
Energy production from wind turbine subsystem & $3.27 \mathrm{GWh} / \mathrm{yr}$. \\
Energy production from biomass-gasified subsystem & $9.43 \mathrm{GWh} / \mathrm{yr}$. \\
Total energy production & $3.83 \mathrm{GWh} / \mathrm{yr}$. \\
\hline
\end{tabular}




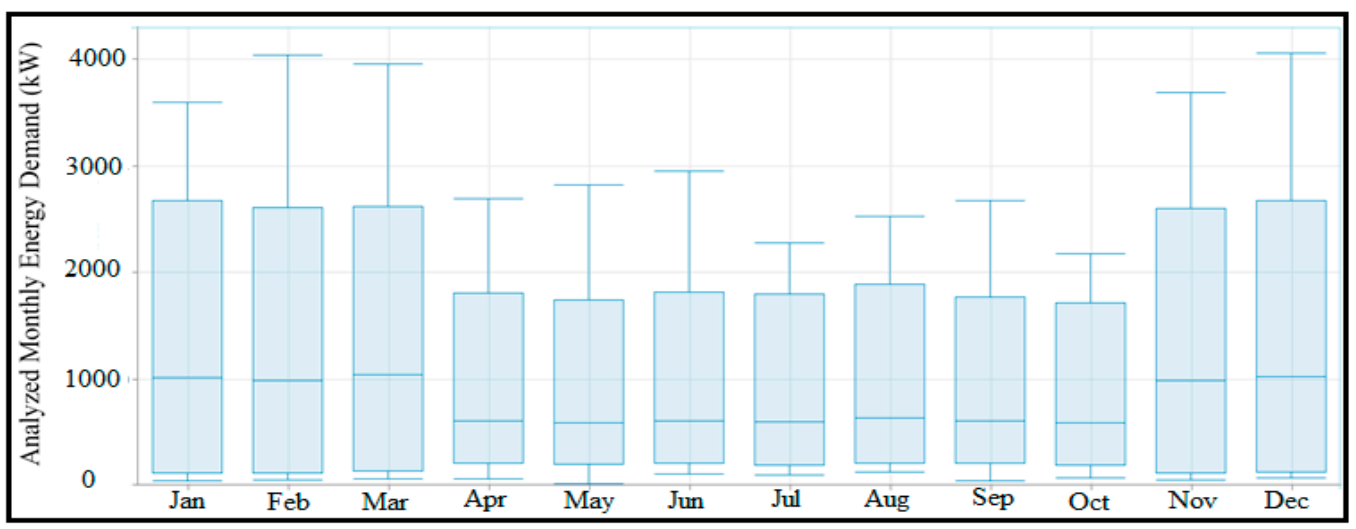

Figure 4. The site's analyzed monthly energy demand data for the HOMER optimization.

From the optimization results presented, with the cumulative energy production of about 16.53 GWh/yr., and the shares of the subsystem components, different scenarios were formulated. The first being the conventional system scenario based on the country's baseline generation data of 2014, and considered as the grid-only power case. The other scenarios were the hybrid renewable grid-integration scenario, based on the shares of contributing subsystems to the total for each case in the optimization results of the Table 3. The analyses of the different scenarios with the assumptions made were presented in Table 4.

Table 4. The different scenarios with their analyzed mix ratios. [HFO, heavy fuel oil; NG, natural gas.]

\begin{tabular}{|c|c|}
\hline Scenarios with Description and Assumptions & Mix Specification \\
\hline $\begin{array}{l}\text { 1st Scenario: Assuming the } 16.53 \mathrm{GWh} \text { is being } \\
\text { sourced from the grid. That is, grid-only power for } \\
\text { the demand side, taking the baseline } 2014 \text { generation } \\
\text { mix path of the country. }\end{array}$ & $\begin{array}{c}\text { Total-16.53 GWh (Generation mix below) } \\
\text { N.G— } 60 \% \\
\text { HFO- } 20 \% \\
\text { Hydro- } 20 \%\end{array}$ \\
\hline $\begin{array}{l}\text { 2nd Scenario: Assuming the } 16.53 \mathrm{GWh} \text { goes to } \\
\text { scaled hybrid PV/wind power solely, by neglecting } \\
\text { the bio-genset component of the HOMER results in } \\
\text { the study location. }\end{array}$ & $\begin{array}{c}\text { Total-16.53 GWh (Generation mix below) } \\
\text { Solar PV— } 25.75 \% \\
\text { Wind power- 74.25\% }\end{array}$ \\
\hline $\begin{array}{l}\text { 3rd Scenario: Assuming the } 16.53 \text { GWh goes to scaled } \\
\text { hybrid PV/biomass-biogas power solely, by } \\
\text { neglecting the wind power component of the } \\
\text { HOMER results in the study location. }\end{array}$ & $\begin{array}{c}\text { Total-16.53 GWh (Generation mix below) } \\
\text { Solar PV— 46.05\% } \\
\text { Biomass-biogas power- } 53.95 \%\end{array}$ \\
\hline $\begin{array}{l}\text { 4th Scenario: Assuming the } 16.53 \text { GWh goes to scaled } \\
\text { hybrid wind/biomass-biogas power solely, by } \\
\text { neglecting the solar PV component of the HOMER } \\
\text { results in the study location. }\end{array}$ & $\begin{array}{c}\text { Total-16.53 GWh (Generation mix below) } \\
\text { Wind power- 71.11\% } \\
\text { Biomass-biogas power- 28.89\% }\end{array}$ \\
\hline $\begin{array}{l}\text { 5th Scenario: Maintaining the } 16.53 \text { GWh for each } \\
\text { share in the hybrid PV/wind/biomass power } \\
\text { integration of the HOMER results in the study } \\
\text { location. }\end{array}$ & $\begin{array}{c}\text { Total-16.53 GWh (Generation mix below) } \\
\text { Solar PV- 19.78\% } \\
\text { Wind power- 57.04\% } \\
\text { Biomass-biogas power- 23.18\% }\end{array}$ \\
\hline
\end{tabular}

Note: The whole scenarios were scaled down to $1 \mathrm{kWh}$ functional unit (FU) each as reference flow for the comparative analyses.

The block diagrams of all the concerned scenarios analyzed in Table 3 of the environmental life cycle assessment have been provided in Figure 5 as the analyzed GaBi models. 


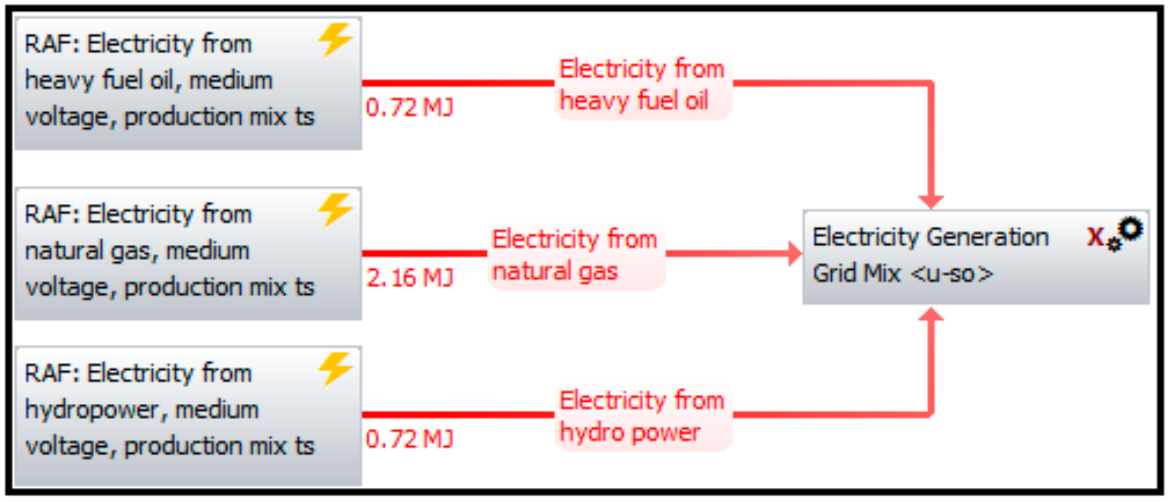

(a) 1st Scenario (the grid-only power/heavy fuel oil (HFO)/gas/hydro conventional power system)

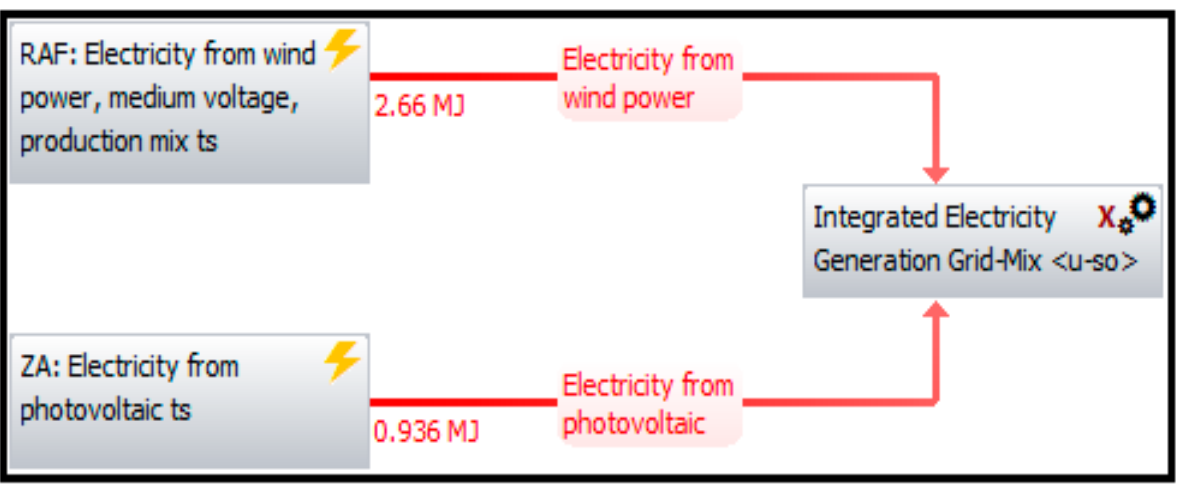

(b) 2nd Scenario (PV/wind integrated power system)

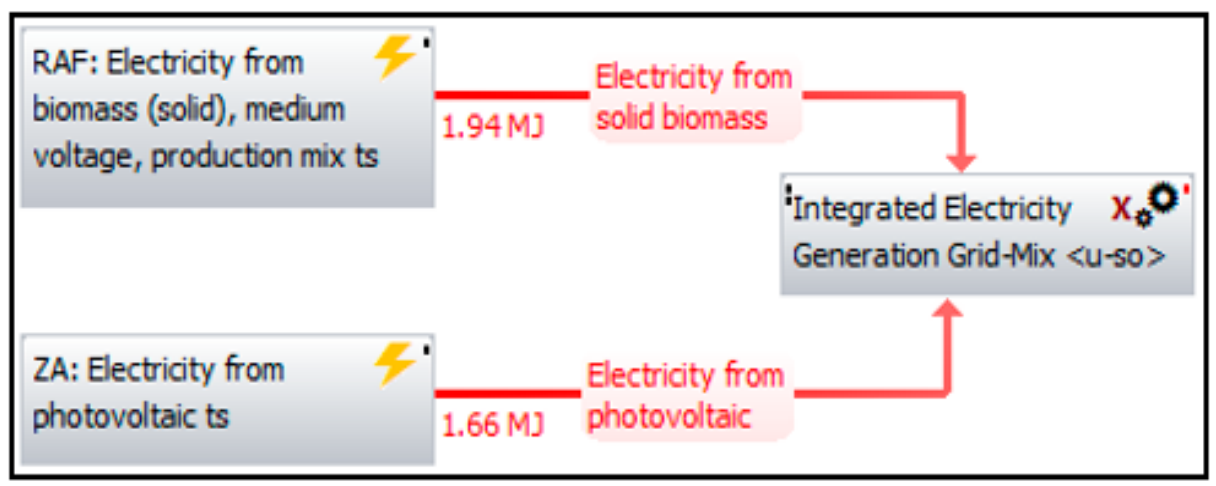

(c) 3rd Scenario (PV/biomass-biogas integrated power system)

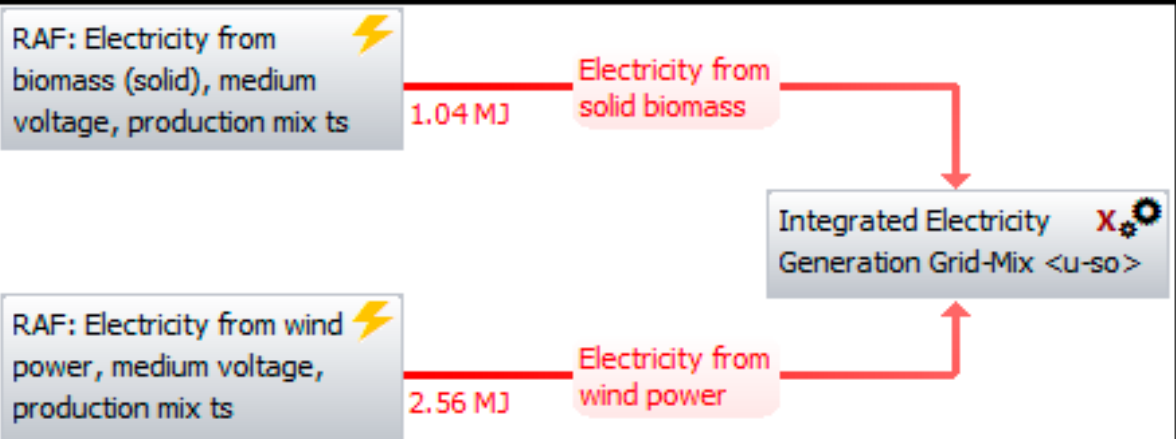

(d) 4th Scenario (wind/biomass-biogas integrated power system)

Figure 5. Cont. 


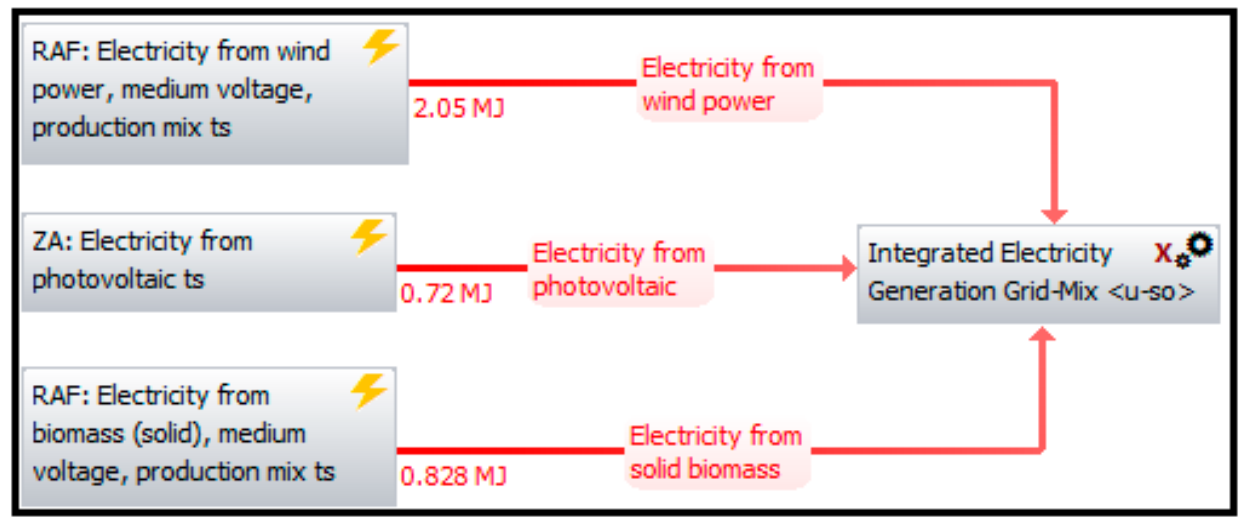

(e) 5th Scenario (PV/wind/biomass-biogas integrated power system)

Figure 5. Models for the different scenarios developed in Ganzheitliche Bilanz (GaBi). [Note: The 1 $\mathrm{kWh}$ functional unit $(\mathrm{FU})$ is equivalent to the $3.6 \mathrm{MJ}$ total reference flow in each of the scenarios shown]. (ZA, South African data; RAF, data for Africa on average; PV, photovoltaics.).

In line with the different analyzed mix data shown in Figure 4, the GaBi software electricity processes data used for the different technologies involved were electricity generation from natural gas, electricity generation from hydropower, electricity generation from solar PV, electricity generation from wind power, and electricity generation from biomass-biogas power. These were mostly "RAF" data, that is data for the African continent on average, however, for the photovoltaic process, the South African data (ZA) was incorporated, being also African-based data because of the absence of RAF data in that regard. The specified year interval from the database was from 2014 to 2020, hence a six-year validity. The application of the RAF data throughout, coupled with the application of South African data (ZA) for the photovoltaic process becomes necessary and worth doing. This is because the analyzed data are from African continent, and based on African regulations, efficiency of operations, and equipment. Overall, this was because of the absence of data specifically for the case study country point of view.

Lastly, in view of the nature of the data collected for the concerned processes highlighted in the preceding paragraph, uncertainty analyses were conducted based on the pedigree matrix data, coupled with the Excel program, in accounting for the different variations in the impact data as a quality measure. This incorporates basic uncertainties, as well as the different default uncertainty factors with their level assignments for the different processes in getting the overall uncertainties and standard deviations that are applicable for the band estimations of the impacts data. The data distributions considered were lognormal and normal, based on a confidence interval of $68 \%$.

The overall and summarized methodology for the environmental life cycle assessment task has been presented in Figure 6, in a block flow for more clarity to the readers. 


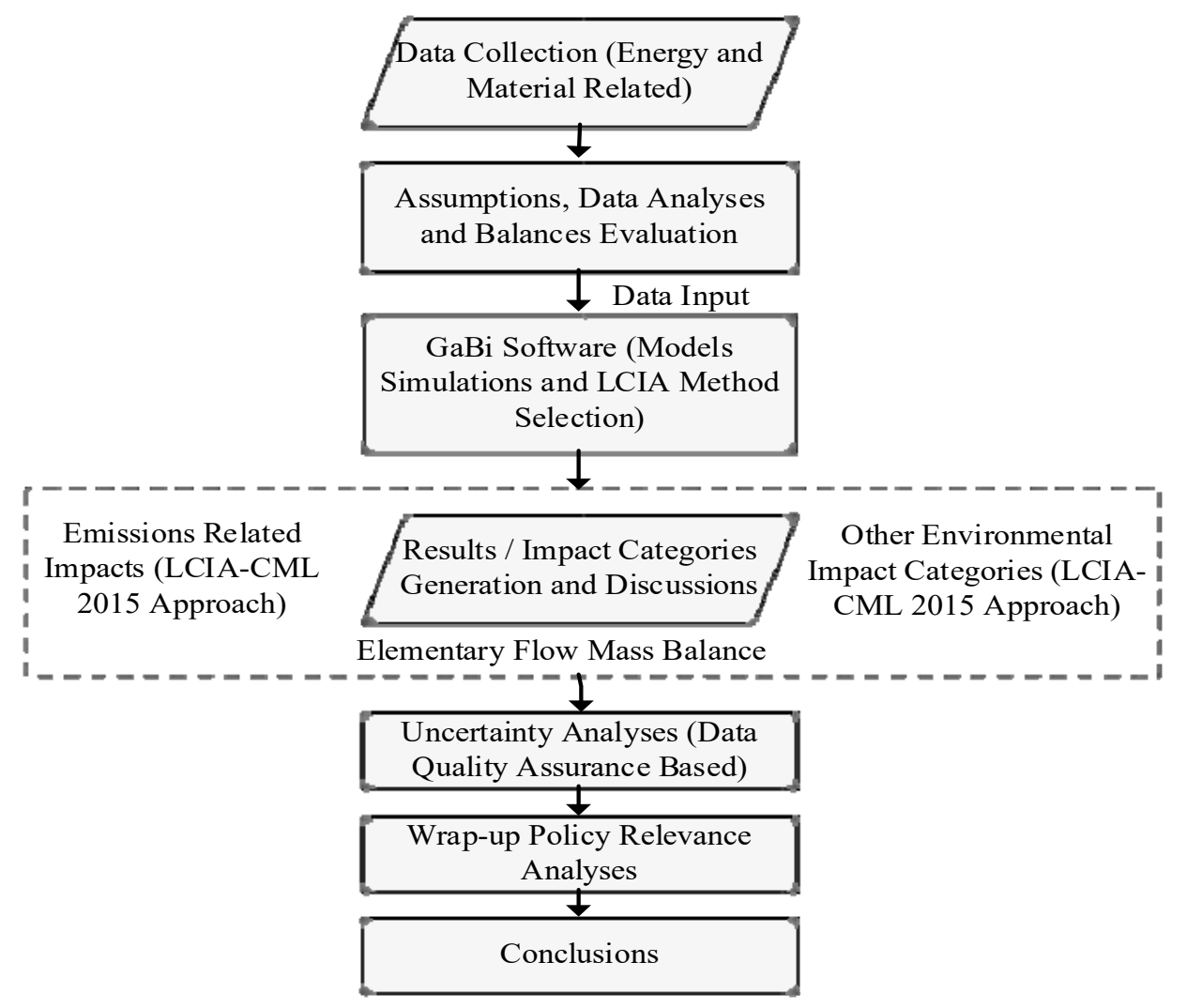

Figure 6. LCA Summarized flow steps adopted in the research.

\section{Results and Discussion}

The results of the defined LCA scope, namely the elementary mass balance results, as well as the results of the considered impact categories for the different hybrid scenarios were successful as displayed and discussed next.

\subsection{Elementary Mass Flow Balance and Interpretations}

The elementary flow balance based on the already explained participating parameters and indicators for all the considered scenarios of the LCA system were successfully procured, as presented in Table 5. It became obvious from the estimated total resource values for the different scenarios that first scenario (i.e., the conventional system path) has the largest value, which is $1.84 \times 10^{3} \mathrm{~kg} / \mathrm{kWh}_{\text {elec. }}$, and is mostly attributable to the hydro portion of it, showing its high materials and specific energy requirement. The scenario with the lowest resource input is the fourth one, specifically the hybrid wind/biomass-biogas power considerations in the study location, with its value being $32 \mathrm{~kg} / \mathrm{kWh}_{\text {elec }}$. Moving to the output parameters of the balance, beginning with the aggregate deposited goods, third scenario (i.e., hybrid PV/biomass-biogas power) is considered with the highest value, while the first scenario has the lowest. On the aggregate emissions to air, the same third scenario was considered to have the highest value compared with others, which is in contrast to the aggregate emissions to freshwater where the first scenario contributes the most, leaving the third scenario with the lowest contribution. third scenario is seen as having largest contribution on the other output indicators namely the aggregate emissions to seawater, aggregate emissions to agricultural soils, and aggregate emissions to industrial soil. These remaining indicators leave the first scenario with the least share but with the exception of the aggregate emissions to agricultural soil where the second scenario was seen with the least contribution. Therefore, it can finally be deduced, as reflected in the hybrid system, that, based on specific technologies, solar PV contributes the most on the aggregate deposited goods, emissions to industrial soil, and emissions to seawater. Whereas, the biomass-biogas power system is seen with 
major contributions to the aggregate emissions to air and agricultural soil. Emissions to fresh water major impact linked to the conventional system could be attributed to hydropower participation. The wind power system is seen with low and moderate impacts of all the indicators.

Table 5. The grid power mix mass balance for all the consecutive scenarios.

\begin{tabular}{|c|c|c|c|}
\hline \multicolumn{2}{|c|}{ Resource Input } & \multicolumn{2}{|c|}{ Tracked Output } \\
\hline Mass by Scenario & Value by Power System & Impact Indicator & Value by Scenario \\
\hline 1st Scenario: $1.84 \times 10^{3} \mathrm{~kg}$ & $\begin{array}{l}\text { HFO power: } 26.3 \mathrm{~kg} \\
\text { Hydropower: } 1.78 \times 10^{3} \mathrm{~kg} \\
\text { NG power: } 42.2 \mathrm{~kg}\end{array}$ & $\begin{array}{l}\text { Aggregate deposited } \\
\text { goods }\end{array}$ & $\begin{array}{l}\text { 1st: } 0.0130 \mathrm{~kg} \\
\text { 2nd: } 0.0903 \mathrm{~kg} \\
\text { 3rd: } 0.1130 \mathrm{~kg} \\
\text { 4th: } 0.0492 \mathrm{~kg} \\
\text { 5th: } 0.0788 \mathrm{~kg}\end{array}$ \\
\hline 2nd Scenario: $46.1 \mathrm{~kg}$ & $\begin{array}{l}\text { PV power: } 37.4 \mathrm{~kg} \\
\text { Wind power: } 8.71 \mathrm{~kg}\end{array}$ & $\begin{array}{l}\text { Aggregate emissions to } \\
\text { air }\end{array}$ & $\begin{array}{l}\text { 1st: } 10.60 \mathrm{~kg} \\
\text { 2nd: } 5.93 \mathrm{~kg} \\
\text { 3rd: } 44.70 \mathrm{~kg} \\
\text { 4th: } 18.50 \mathrm{~kg} \\
\text { 5th: } 19.20 \mathrm{~kg}\end{array}$ \\
\hline 3rd Scenario: $110 \mathrm{~kg}$ & $\begin{array}{l}\text { PV power: } 66.2 \mathrm{~kg} \\
\text { Bio-power: } 44.1 \mathrm{~kg}\end{array}$ & $\begin{array}{l}\text { Aggregate emissions to } \\
\text { freshwater }\end{array}$ & $\begin{array}{c}\text { 1st: } 1.83 \times 10^{3} \mathrm{~kg} \\
\text { 2nd: } 46.50 \mathrm{~kg} \\
\text { 3rd: } 7.70 \mathrm{~kg} \\
\text { 4th: } 14.10 \mathrm{~kg} \\
\text { 5th: } 40.40 \mathrm{~kg}\end{array}$ \\
\hline 4th Scenario: $32 \mathrm{~kg}$ & $\begin{array}{l}\text { Wind power: } 8.36 \mathrm{~kg} \\
\text { Bio-power: } 23.7 \mathrm{~kg}\end{array}$ & $\begin{array}{c}\text { Aggregate emissions to } \\
\text { seawater }\end{array}$ & $\begin{array}{l}\text { 1st: } 0.009 \mathrm{~kg} \\
\text { 2nd: } 0.094 \mathrm{~kg} \\
\text { 3rd: } 0.200 \mathrm{~kg} \\
\text { 4th: } 0.023 \mathrm{~kg} \\
\text { 5th: } 0.090 \mathrm{~kg}\end{array}$ \\
\hline \multirow{2}{*}{ 5th Scenario: $54.3 \mathrm{~kg}$} & \multirow{2}{*}{$\begin{array}{l}\text { PV power: } 28.80 \mathrm{~kg} \\
\text { Wind power: } 6.71 \mathrm{~kg} \\
\text { Bio-power: } 18.80 \mathrm{~kg}\end{array}$} & $\begin{array}{l}\text { Aggregate emissions to } \\
\text { agricultural soil }\end{array}$ & $\begin{array}{l}\text { 1st: } 1.09 \times 10^{-9} \mathrm{~kg} \\
\text { 2nd: }-1.48 \times 10^{-9} \mathrm{~kg} \\
\text { 3rd: } 4.55 \times 10^{-7} \mathrm{~kg} \\
\text { 4th: } 2.44 \times 10^{-7} \mathrm{~kg} \\
\text { 5th: } 1.93 \times 10^{-7} \mathrm{~kg}\end{array}$ \\
\hline & & $\begin{array}{l}\text { Aggregate emissions to } \\
\text { industrial soil }\end{array}$ & $\begin{array}{l}\text { 1st: } 4.31 \times 10^{-9} \mathrm{~kg} \\
\text { 2nd: } 5.29 \times 10^{-7} \mathrm{~kg} \\
\text { 3rd: } 7.94 \times 10^{-7} \mathrm{~kg} \\
\text { 4th: } 1.55 \times 10^{-8} \mathrm{~kg} \\
\text { 5th: } 4.19 \times 10^{-7} \mathrm{~kg}\end{array}$ \\
\hline
\end{tabular}

Note: Heavy metals are associated with the emissions to air, emissions to freshwater, emissions to seawater, emissions to agricultural soil, and emissions to industrial soil, and could include Cadmium (Cd), Lead ( $\mathrm{Pb}$ ), Arsenic (As), Mercury (Hg), Chromium (Cr), Thallium (Tl), and so on. Radioactive emissions are associated with deposited goods, emissions to freshwater and seawater, and could include Carbon $(\mathrm{C})$, Cesium $(\mathrm{Ce})$, Uranium $\left(\mathrm{U}_{235}\right)$, Hydrogen $(\mathrm{H})$ and so on. Stockpile Goods are associated with deposited goods, and could include hazardous wastes (deposited), overburden (deposited), slag (deposited), spoil (deposited), tailings (deposited), and waste (deposited). Volatile organic compounds (VOC) are associated with emissions to air with examples such as formaldehyde, acetone, acetic acid, some alkanols and alkanals and so on. Finally, organic/halogenated organic and inorganic emissions are associated with emissions to air, emissions to freshwater and seawater, emissions to agricultural and industrial soils.

\subsection{Impact Categories Results and Interpretations}

The results in specifics for the various environmental impact categories selected namely GWP, $\mathrm{AP}, \mathrm{EP}, \mathrm{ODP}, \mathrm{HTP}$, and $\mathrm{ADP}_{\text {fossils }}$, for the comparative assessment of the different scenarios considered were successfully procured as depicted and analyzed next.

\subsubsection{Global Warming Potential (GWP) Results}

The global warming potential arising from the release of greenhouse gases (i.e., $\mathrm{CO}_{2}, \mathrm{CH}_{4}, \mathrm{~N}_{2} \mathrm{O}$, and VOC among others, but majorly $\mathrm{CO}_{2}$ ) is a critical criterion in the power systems decision. This is owing to climate variability and climate change and their strong negative consequences to the environment. The results of this analysis are presented in Figure 7. It is obvious that first scenario where the conventional systems pattern was taken in maintaining the BAU trajectory has the highest 
GWP, valued at $507 \mathrm{~g} \mathrm{CO}_{2}$-eq./ $/ \mathrm{kWh}_{\text {elec. }}$ This was largely because of the fact that the natural gas and oil power plants are fossil-based, with high direct emissions during the operational stage in the life cycle. However, on the renewables-integration scenarios, the value has decreased significantly to some extent throughout. The fourth scenario, i.e., the scenario with the hybrid wind/biomass-biogas power system consideration was found to have the lowest GWP value, which is $17.8 \mathrm{~g} \mathrm{CO}_{2}$-eq. $/ \mathrm{kWh}_{\text {elec. }}$. The renewable-based scenario with relatively the highest relative GWP value was found to be 52.9 $\mathrm{g} \mathrm{CO}_{2}$-eq./ $/ \mathrm{kWh}_{\text {elec. }}$ for the hybrid PV/biomass-biogas power system in the third scenario. This is a clear indication that the indirect greenhouse gas emissions associated with all the processes involved in the entire life cycle assessment of the renewable-based scenarios favour wind power generations in the systems architecture as compared with solar PV being the biggest contributor to the GWP in the renewable scenarios, and the biomass-biogas power system with intermediate greenhouse gas emissions impact. On a final note, the GWP of the renewable integration in the fifth scenario, where the complete hybrid system exists based on the full share of each in the HOMER optimization results was noted as $27.4 \mathrm{~g} \mathrm{CO}_{2}$-eq./ $/ \mathrm{kWh}_{\text {elec. }}$

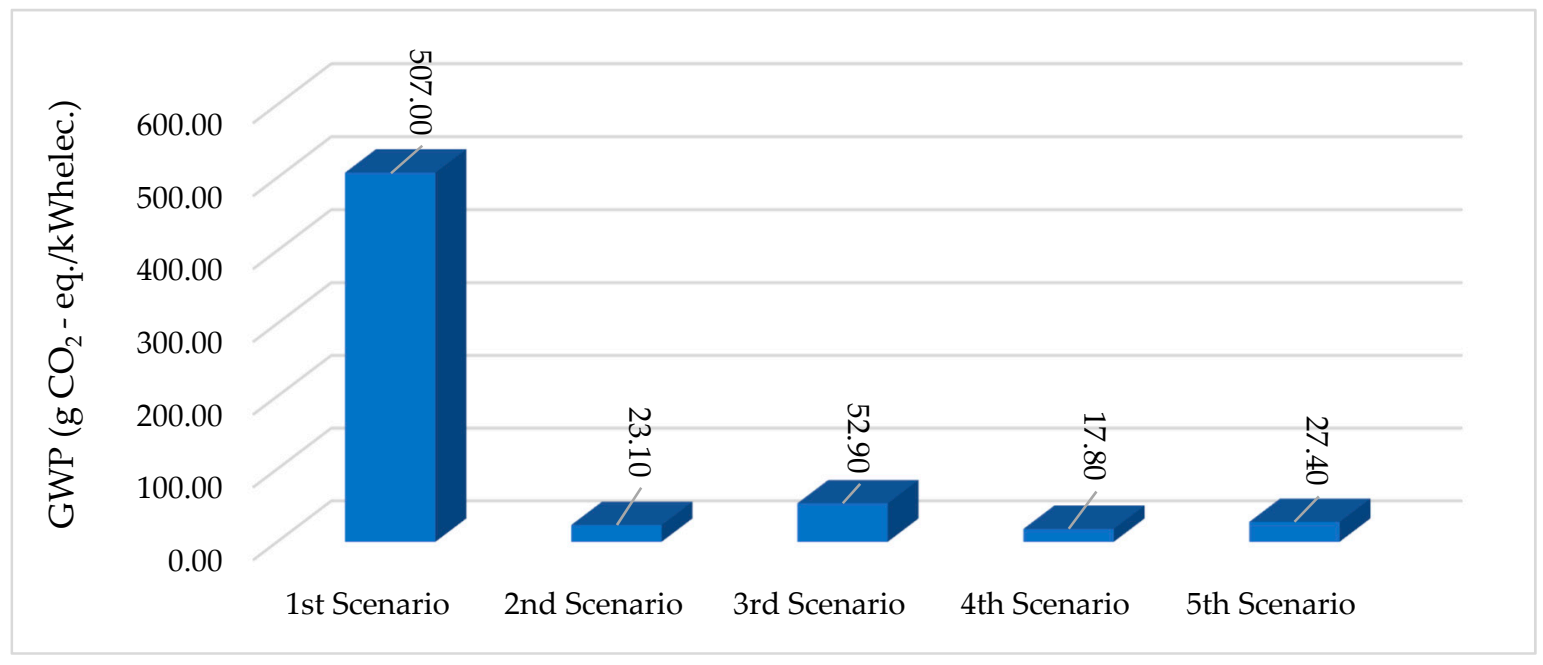

Figure 7. Global warming potential (GWP) results for all the scenarios.

\subsubsection{Acidification Potential (AP) Results}

Regarding the acidification potential (AP), which is based on the air pollutants viz. such as $\mathrm{SO}_{2}$, $\mathrm{HCl}, \mathrm{NH}_{3}$, and $\mathrm{HF}$ gases, the result is obvious with the obtained values for all the scenarios in Figure 8 . It is evident that first scenario which has the hybrid conventional sources incorporated in its system architecture contributes the most in the AP indicator, valued at $5.32 \mathrm{~g} \mathrm{SO}_{2}$-eq. $/ \mathrm{kWh}_{\text {elec. }}$ This is because of the complexity in the system where the fossil-based subcomponents are associated with acidification impact air pollutants apart from the greenhouse gas emissions largely in the operational level of the life cycle. The third scenario (hybrid PV/biomass-biogas) has got the second largest contribution to this impact category, owing to the presence of the biomass-biogas complex system that also causes the release of direct acidification impact air pollutants, apart from the direct greenhouse gas emissions at the operational level for power generation. However, the share of the biomass-biogas in the hybrid renewable system scenarios with such is not strong enough to compete with the share and complexity of the conventional system scenario, into which the oil and the large natural gas-based subsystems are incorporated. The existence of the biomass-biogas system impact also reflected in the fourth and fifth scenarios making them the third and fourth highest contributors in the category respectively. The second scenario being the hybrid $\mathrm{PV} /$ wind power system is considered with the lowest contribution in the impact. 


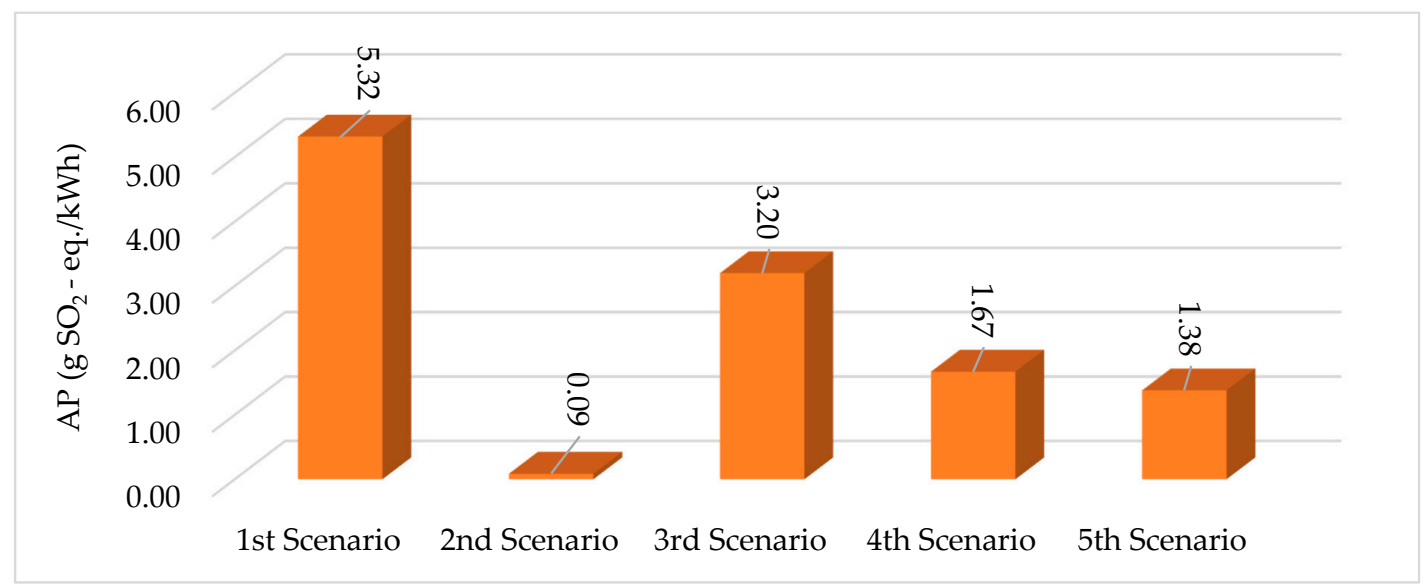

Figure 8. Acidification potential (AP) results for all the consecutive scenarios.

\subsubsection{Eutrophication Potentials (EP) Results}

Figure 9 depicts the eutrophication potential (EP) of the different scenarios. This impact is to water bodies for oxygen depletion owing to excessive minerals and nutrients such as $\mathrm{N}_{2}, \mathrm{NO}_{\mathrm{x}}, \mathrm{NH}_{4}{ }^{+}$, $\mathrm{PO}_{4}{ }^{3-}$, and $\mathrm{P}$. The major contributor to the EP impact was found to be the third Scenario having the hybrid PV/biomass power system. The value was $0.38 \mathrm{~g}$ Phosphate-eq./ $/ \mathrm{kh}_{\text {elec. }}$. The second scenario with the incorporation of the hybrid PV/wind power system is seen with the lowest impact where its EP value was around $0.01 \mathrm{~g}$ Phosphate-eq. $/ \mathrm{kWh}_{\text {elec. }}$. It can be implied that the biomass-biogas power system has a greater negative impact to the EU category as the third scenario reflected in the fourth and fifth scenarios owing to its existence, making them also high. Although the first scenario also has got a relatively high contribution and specifically the third-most, contributing to the impact category. Therefore, it can be deduced that the more the biomass-biogas power in a hybrid system, the more the potential release of the minerals and nutrients inducing the excessive growth of aquatic plants, especially algae, as the nutrients and minerals have a high tendency of contacting water bodies, and ultimately a higher tendency for oxygen depletion in the water bodies.

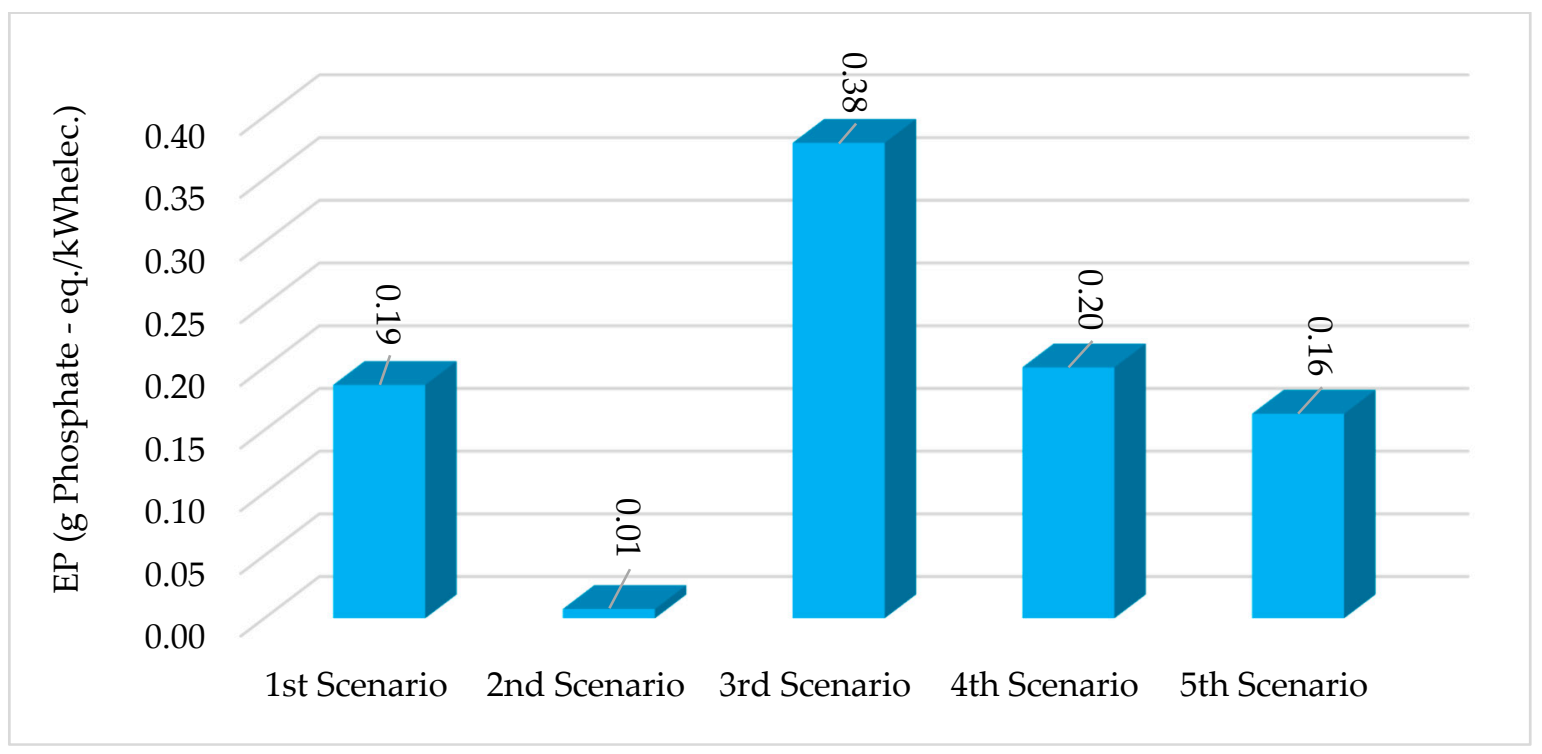

Figure 9. Eutrophication potential (EP) results for all the consecutive scenarios. 


\subsubsection{Ozone Layer Depletion Potentials (ODP) Results}

Moving to the ozone-layer depletion potential (ODP) impact category as a crucial concern, the results are presented in Figure 10 of the different scenarios and basically associated with the release of tri-chloro fluoro carbon (CFC) and other halogenated compounds. It must first be stated that anthropogenic activities being energy-related in this case, could have a strong impact on the stratospheric component of the ecosystem depending on the emitting gases on overall processes in systems life cycle. The results clearly show values ranging from $2.74 \times 10^{-13} \mathrm{~g} \mathrm{R} 11^{-e q} / \mathrm{kWh}$ elec. for the first scenario to the $1.73 \times 10^{-10} \mathrm{~g} \mathrm{R}_{11}$-eq./ $/ \mathrm{kWh}_{\text {elec. }}$ for the third scenario. Although it could be said that all the values were negligible and in extremely smaller fractions, hence, the impact to the ozone layer might be infinitesimal. In a nutshell, it can be said that technologically-speaking, as a reflection to what is seen in the hybrids, the solar PV component is the worst of all in the impact category due to its high potential release of the ozone depleting gases. This could be attributed to the measures put in place mainly during the fabrication stage of the materials of the component. Hence the more the share of the PV component to the system, the greater the tendency for the release of ozone depleting gases in the entire life cycle, based on negligible fractions.

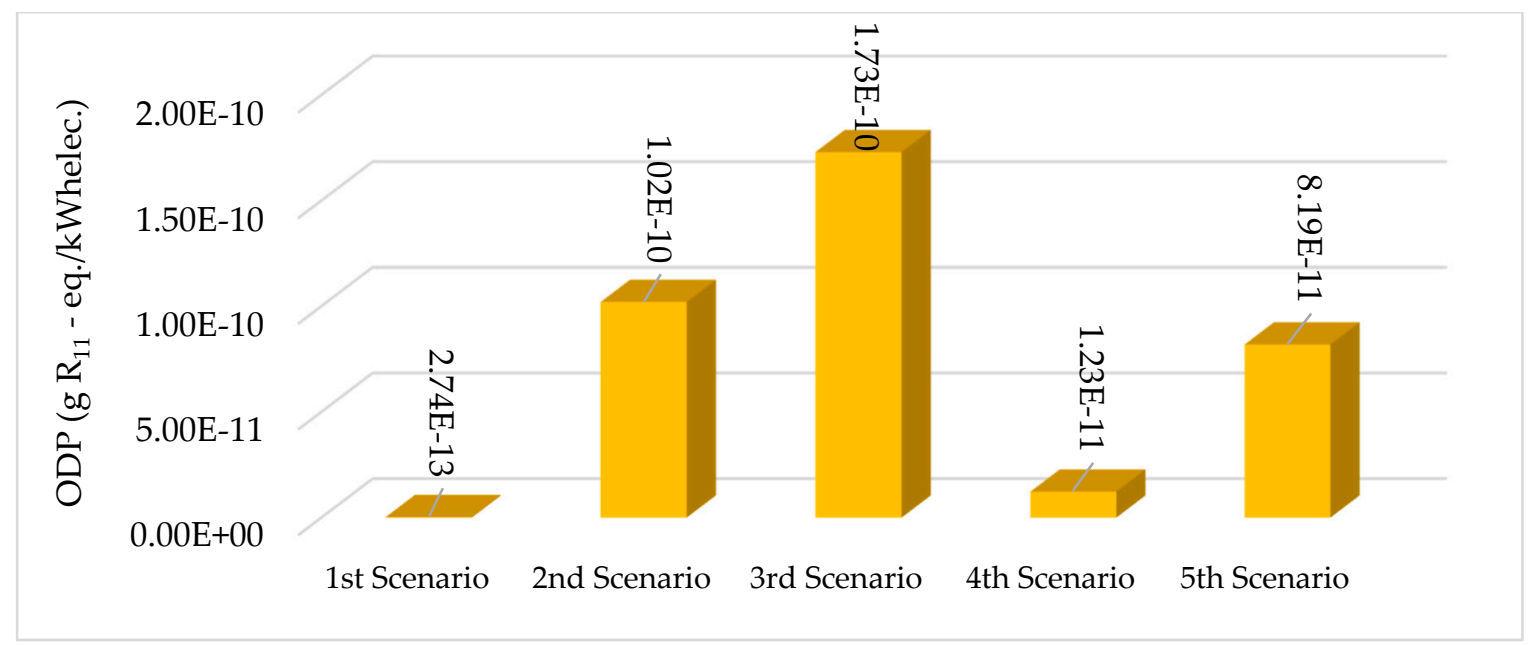

Figure 10. Ozone layer depletion potential (ODP) results for all the consecutive scenarios.

\subsubsection{Human Toxicity Potential (HTP) Results}

The human impact from anthropogenic activities for energy generation is worthy of consideration as well. The potential release of harmful substances into the components of the ecosystem namely soil, water, and air, which ultimately affects the quality of human health was analyzed with the results presented in Figure 11. It is obvious from the results that the first scenario has got a value of around $177 \mathrm{~g}$ DCB-eq./ $\mathrm{kWh}$ elec., which exceeded all the values for the renewable integration scenarios, hence the major contributor to this impact category. On the renewable integration scenarios that is from second to fifth scenarios, third scenario (hybrid PV/biomass-biogas power system) followed the first scenario, with an evaluated value of $83.9 \mathrm{~g}$ DCB-eq./ $/ \mathrm{kWh}_{\text {elec. }}$ This makes the fifth and fourth scenarios consisting of the biomass-biogas component to respectively follow the third scenario with values 37.9 g DCB-eq./kWh $\mathrm{klec}_{\text {. }}$ and $35.6 \mathrm{~g}$ DCB-eq./kWh $\mathrm{klec}_{\text {. }}$ respectively. Hence the biomass system could be seen with high impact on the renewable integration scenarios, and could be attributed to a greater release of toxic substances mainly heavy metals - to air, water, or soil during its fabrication stages. Also, because of the tendency of the release of harmful gases in operation stage to the humans, which is similar to the conventional case-participating fossils as compared with the solar PV and wind power components. 


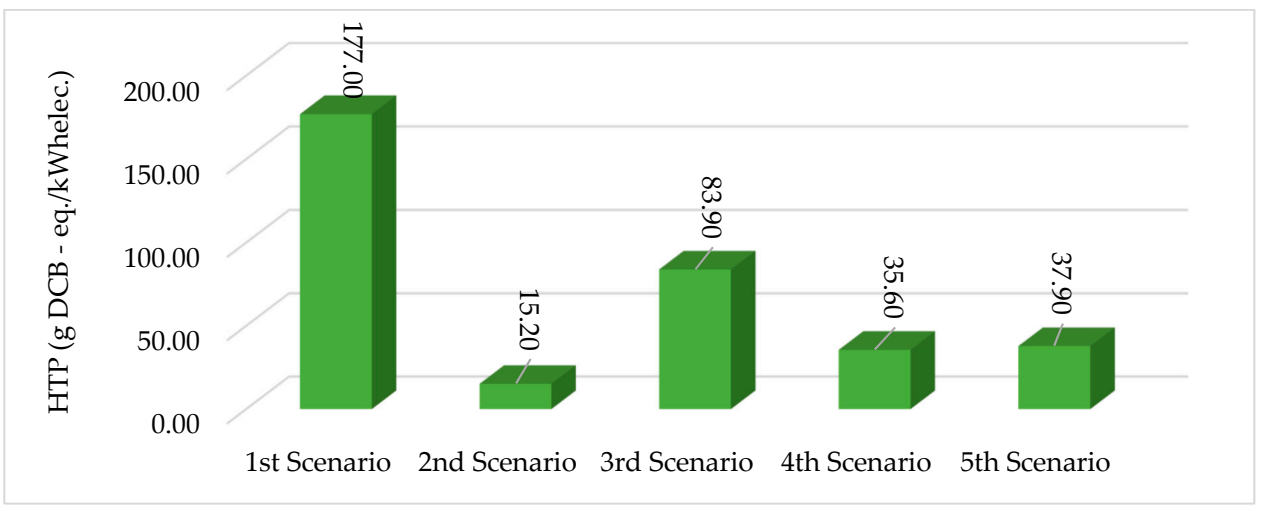

Figure 11. Human toxicity potential (HTP) results for all the consecutive scenarios.

\subsubsection{Abiotic Depletion Potentials ( $\left.\mathrm{ADP}_{\text {fossils }}\right)$ Results}

These evaluations differ from the preceded impacts evaluations, as it carried the unit of energy with the software default setting of Mega Joule (MJ). On the basis of the already known definition of this impact category however, in this regard, relating to fossil fuels, which is the fossil energy utilized throughout the entire life cycle of each of the sub-components in the overall systems, the results obtained of all the scenarios are presented in Figure 12. It is evident that the first scenario has got the largest value, which is $7.46 \mathrm{MJ} / \mathrm{kWh}_{\text {elec. }}$, obviously because of the higher consumption of fossil energy in the life cycle of the considered sub-components of the system, especially the oil and natural gas-based system subcomponents, that majorly needed fossil fuels specifically oil and natural gas in operational stage to generate electricity on a Rankine cycle basis. Moving to the scenarios for renewable integration, it is noted that third scenario (hybrid PV/biomass-biogas power) followed the first scenario with a value of around $0.6 \mathrm{MJ} / \mathrm{kWh}_{\text {elec }}$. The fourth scenario (hybrid wind/biomass-biogas) has the lowest of all, with a value of $0.2 \mathrm{MJ} / \mathrm{kWh}_{\text {elec. }}$ This could be deduced technologically speaking as reflected in the hybrids that solar PV consumes more fossil energy, while wind power consumes the lowest, and the biomass-biogas power system is intermediate. These fossil energies consumptions assigned to the hybrid renewable systems majorly arise during fabrications of components of the systems as machines powered by fossil fuels are needed, and hence are considered indirect fossil energy consumptions in the life cycle analyses.

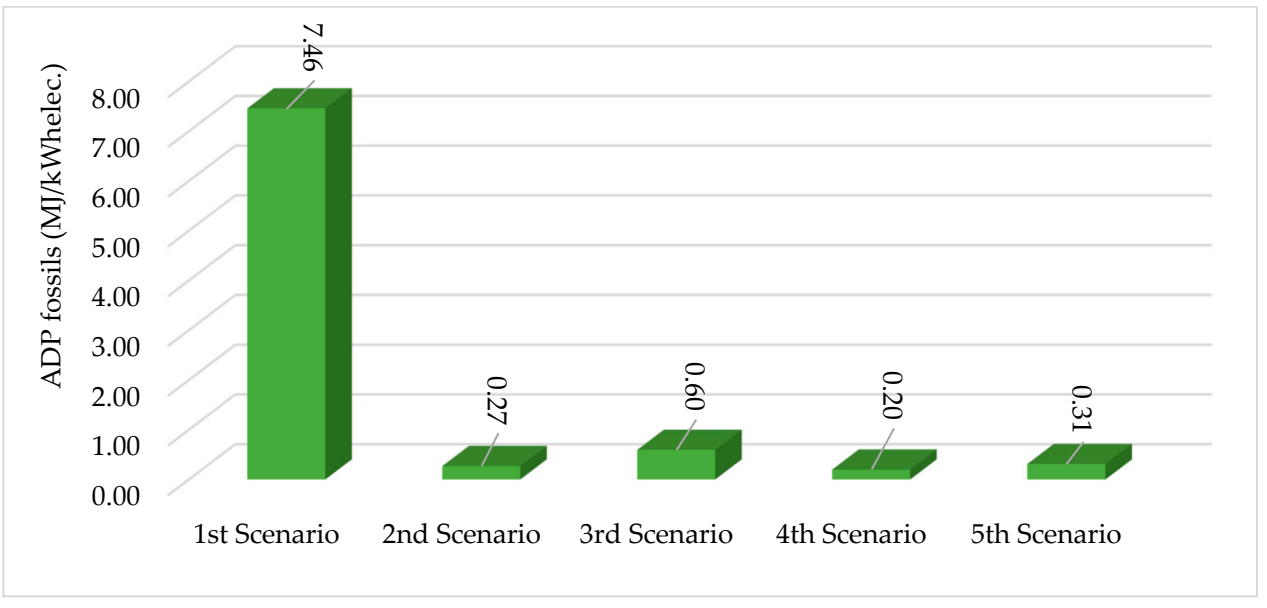

Figure 12. Abiotic depletion potential $\left(\mathrm{ADP}_{\text {fossils }}\right)$ results for all the consecutive scenarios.

\subsection{Uncertainty Analyses Results}

The baseline pedigree matrix employed in the uncertainty analyses was developed by Funtowiez and Ravetz in 1990 as a tool for coding a qualitative assessment of data due to uncertainty challenges [33]. 
Table 6 provided the default uncertainty factors applicable. Table 7 describes in much detail, the pedigree matrix and the evaluation approach in the Excel program for the uncertainties linked to the environmental impact data.

Table 6. Default uncertainty factors incorporated in the uncertainty evaluations [34].

\begin{tabular}{cccccc}
\hline Indicators/Levels & $\mathbf{1}$ & $\mathbf{2}$ & $\mathbf{3}$ & $\mathbf{4}$ & $\mathbf{5}$ \\
\hline Reliability & 0.000 & 0.0006 & 0.002 & 0.008 & 0.04 \\
Completeness & 0.000 & 0.0001 & 0.0006 & 0.002 & 0.008 \\
Temporal Correlation & 0.000 & 0.0002 & 0.002 & 0.008 & 0.04 \\
Geographical Correlation & 0.000 & $2.5 \times 10^{-5}$ & 0.0001 & 0.0006 & 0.002 \\
Further Technological Correlation & 0.000 & 0.0006 & 0.008 & 0.04 & 0.12 \\
\hline
\end{tabular}

Table 7. Overall pedigree matrix for the uncertainty evaluations program.

\begin{tabular}{|c|c|c|c|c|c|}
\hline Levels/Indicators & 1 & 2 & 3 & 4 & 5 \\
\hline \multicolumn{6}{|c|}{ Level choice } \\
\hline \multicolumn{6}{|c|}{ Level choice } \\
\hline $\begin{array}{l}\text { Geographical } \\
\text { correlation }\end{array}$ & $\begin{array}{l}\text { Data from area under } \\
\text { study }\end{array}$ & $\begin{array}{l}\text { Averaged data from } \\
\text { larger area in which } \\
\text { the area under study is } \\
\text { included }\end{array}$ & $\begin{array}{l}\text { Data from area } \\
\text { with similar } \\
\text { production } \\
\text { conditions }\end{array}$ & $\begin{array}{l}\text { Data from area } \\
\text { with slightly } \\
\text { similar production } \\
\text { conditions }\end{array}$ & $\begin{array}{l}\text { Data from } \\
\text { unknown or } \\
\text { distinctly different } \\
\text { area (North } \\
\text { America instead of } \\
\text { Middle East, } \\
\text { OECD-Europe } \\
\text { instead of Russia) }\end{array}$ \\
\hline \multicolumn{6}{|c|}{ Level choice } \\
\hline \multicolumn{6}{|c|}{$\begin{array}{l}\text { Level choices applied for the different processes: } \\
\text { Hydropower Process }[1,3,3,2,3] \text {, natural gas power process }[1,3,3,2,3] \text {, heavy fuel oil power process }[1,3,3,2,3] \text {, wind power process } \\
{[1,3,3,2,3] \text {, biopower process }[1,3,3,2,3] \text {; solar PV process }[1,4,3,3,3] \text {. }} \\
\text { Extra Indicators: } \\
\text { Confidence interval used: } 68 \% \text {; basic uncertainty applied for lognormal distribution: } 1.00 \text {; basic uncertainty applied for the normal } \\
\text { distribution: } 0 \% \text {. } \\
\text { Analyzed parameters linked to the estimated impacts band: }\end{array}$} \\
\hline
\end{tabular}

Note: Data obtained from the work of [33] as applied in the Excel program for the different evaluations. 
The results of the different impact categories based on the upper and lower limits and in view of having the data as normally distributed and lognormally distributed are given in Tables 8 and 9 respectively. The ranges specified include the actual or true value of the impact categories for the specified case study examined. It is evident from the bands that the normal distribution in virtually all the analyzed data have a larger band gap from the top cap to the mid values than the lognormal distribution. On the other hand, meanwhile, the lognormal distribution case has a larger gap from the mid values to the bottom cap. This is because of the orientations of the distributions as the normal is symmetrical whereas the lognormal is right-skewed. This shows the advantage and disadvantage of the two data distribution cases depending on different circumstance, as the normal distribution tends to give ranges with proximity and ease to the exact values when falling on the lower cap than the lognormal distribution, and vice versa.

Table 8. The analyzed impact categories band (normal distribution case).

\begin{tabular}{|c|c|c|c|c|c|}
\hline Scenarios & 1st Scenario & 2nd Scenario & 3rd Scenario & 4th Scenario & 5th Scenario \\
\hline \multirow{3}{*}{$\begin{array}{l}\text { GWP (g CO2 } \\
\text { eq./kWh } \text { elec. } / \text { Lower limit } \\
\text { GWP (g CO2 eq./kWh } \\
\text { GWP (g CO2 } 2 \\
\text { eq./kWh } \text { elec. }) / \text { Upper limit }\end{array}$} & 398.494 & 17.9 & 41.15 & 13.97 & 21.3 \\
\hline & 507.00 & 23.1 & 52.9 & 17.80 & 27.4 \\
\hline & 614.306 & 28.3 & 64.65 & 21.55 & 33.38 \\
\hline \multirow{3}{*}{$\begin{array}{l}\mathrm{AP}(\mathrm{g} \mathrm{SO} 2 \text { eq./} / \mathrm{kWh} \text { elec. } / \text { Lower } \\
\text { limit } \\
\mathrm{AP}\left(\mathrm{g} \mathrm{SO} 2 \mathrm{eq} . / \mathrm{kWh}_{\text {elec. }}\right) \\
\mathrm{AP}\left(\mathrm{g} \mathrm{SO} 2 \text { eq./ } / \mathrm{kWh}_{\text {elec. }}\right) / \mathrm{Upper} \\
\text { limit }\end{array}$} & 4.18 & 0.0697 & 2.514 & 1.32 & 1.077 \\
\hline & 5.32 & 0.09 & 3.2 & 1.67 & 1.38 \\
\hline & 6.44 & 0.1103 & 3.89 & 2.02 & 1.663 \\
\hline \multirow{3}{*}{$\begin{array}{l}\text { EP }(\mathrm{g} \text { Phosphate } \\
\text { eq./kWh } / \mathrm{klec}) / \text { Lower limit } \\
\text { EP }(\mathrm{g} \text { Phosphate eq./kWh } \\
\text { EP }(\mathrm{g} \text { Phosphate }) \\
\text { eq./kWh }\end{array}$} & 0.15 & $5.76 \times 10^{-3}$ & 0.298 & 0.161 & 0.134 \\
\hline & 0.19 & 0.01 & 0.38 & 0.2 & 0.16 \\
\hline & 0.22 & $9.08 \times 10^{-3}$ & 0.462 & 0.242 & 0.197 \\
\hline \multirow{3}{*}{$\begin{array}{l}\text { ODP (g R11 } \\
\text { eq./kWhelec.)/Lower limit } \\
\left.\text { ODP (g R11 eq./kWh } h_{\text {elec. }}\right) \\
\text { ODP }(\mathrm{g} \mathrm{R} 11 \\
\text { eq./kWh } \\
\text { elec. }) / \text { Upper limit }\end{array}$} & $2.16 \times 10^{-13}$ & $7.60 \times 10^{-11}$ & $1.34 \times 10^{-10}$ & $9.67 \times 10^{-12}$ & $6.33 \times 10^{-11}$ \\
\hline & $2.74 \times 10^{-13}$ & $1.02 \times 10^{-10}$ & $1.73 \times 10^{-10}$ & $1.23 \times 10^{-11}$ & $8.19 \times 10^{-11}$ \\
\hline & $3.32 \times 10^{-13}$ & $1.18 \times 10^{-10}$ & $2.13 \times 10^{-10}$ & $1.49 \times 10^{-11}$ & $1.01 \times 10^{-10}$ \\
\hline \multirow{3}{*}{$\begin{array}{l}\text { HTP (g DCB } \\
\text { eq./kWh } \text { elec. }_{\text {. }} / \text { Lower limit } \\
\text { HTP (g DCB eq./kWh } \text { elec. }) \\
\text { HTP (g DCB } \\
\text { eq./kWh } / \text { elec. }_{\text {. }} / \text { Upper limit }\end{array}$} & 138.76 & 11.73 & 65.66 & 27.99 & 29.65 \\
\hline & 177.00 & 15.2 & 83.9 & 35.60 & 37.90 \\
\hline & 213.9 & 18.61 & 102.14 & 43.15 & 46.09 \\
\hline \multirow{3}{*}{$\begin{array}{l}\mathrm{ADP}_{\text {fossils }}\left(\mathrm{MJ} / \mathrm{kWh}_{\text {elec. }}\right) / \text { Lower } \\
\text { limit } \\
\mathrm{ADP}_{\text {fossils }}\left(\mathrm{MJ} / \mathrm{kWh}_{\text {elec. }}\right) \\
\mathrm{ADP}_{\text {fossils }}(\mathrm{MJ} / \mathrm{kWh} \text { elec. }) / \text { Upper } \\
\text { limit }\end{array}$} & 5.87 & 0.211 & 0.463 & 0.158 & 0.246 \\
\hline & 7.46 & 0.27 & 0.60 & 0.2 & 0.31 \\
\hline & 9.05 & 0.333 & 0.727 & 0.244 & 0.383 \\
\hline
\end{tabular}

On the basis of the obtained results regarding the different aspects addressed, it is important to note that policy implication is very fundamental. Implementing the different hybrid systems especially the ones observed with the lowest impacts on the environment, requires strong policy back-up and political will. This goes back to the renewable policy instruments both regulatory and economic-based, as well as environmental-related policy concerns. This has helped many advanced countries in boosting their renewable energy supply. Currently, integration of renewable systems singly or in hybrid to the utility grid of the Nigerian context is yet to be realized except for the conventional hydro existing with the fossils in the electricity mix. This is because of many challenges among which is the policy framework. Regulatory instruments, principally the feed-in tariff and net-metering are very necessary for such transition. Although, the country already has the feed-in tariff instrument in force but pending impact. What is strongly required in ensuring the activeness of this instrument, as well as bringing in 
the net-metering in to force are the appropriate designs that ensure favorable pricing mechanisms and other strong features of the instruments. The relevance of the net-metering policy is because of the fact that the renewable energy developers can be consumers at the same time just like the energy system modelling task done as a linkage to this environmental LCA. This cluster of instruments can be made more effective by further incorporating the appropriate economic-based policy instruments, specifically the fiscal policies and the incentives and financing schemes for additional motivations to the private enterprise energy producers. The support schemes should be in such a way that technology transfer and capacity building with ultimate innovations target are strongly covered in the renewable energy domain as strong indicators of research and development (R\&D). In addition to these, environmental compliance support schemes and codes should be assigned in order of merits to the development of projects in boosting the power sector. The merit order should reflect the observed environmental impacts of the different energy systems analyzed here and beyond. Furthermore, suitable policies are necessary, enabling the reduction in the pace of conventional energy sources extraction and utilization. Above all, as a final note, public awareness programs are fundamental, regarding the environmental consequences of the energy operation trajectory, as well as the need for changing the narrative.

Table 9. The analyzed impact categories band (lognormal distribution case).

\begin{tabular}{|c|c|c|c|c|c|}
\hline Scenarios & 1st Scenario & 2nd Scenario & 3rd Scenario & 4th Scenario & 5th Scenario \\
\hline \multirow{3}{*}{ 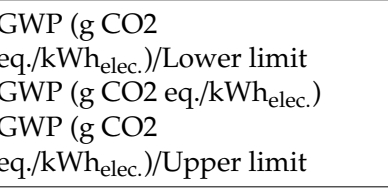 } & 409.796 & 18.47 & 42.42 & 14.37 & 21.95 \\
\hline & 507.00 & 23.1 & 52.9 & 17.80 & 27.4 \\
\hline & 625.772 & 28.89 & 65.97 & 21.94 & 34.04 \\
\hline \multirow{3}{*}{$\begin{array}{l}\mathrm{AP}\left(\mathrm{g} \mathrm{SO} 2 \mathrm{eq} . / \mathrm{kWh} \mathrm{h}_{\text {elec. }}\right) / \text { Lower } \\
\text { limit } \\
\mathrm{AP}(\mathrm{g} \mathrm{SO} 2 \mathrm{eq} . / \mathrm{kWh} \text { elec.) } \\
\mathrm{AP}\left(\mathrm{g} \mathrm{SO} 2 \mathrm{eq} . / \mathrm{kWh} \mathrm{h}_{\text {elec. }}\right) / \mathrm{Upper} \\
\text { limit }\end{array}$} & 4.30 & 0.072 & 2.587 & 1.36 & 1.108 \\
\hline & 5.32 & 0.09 & 3.2 & 1.67 & 1.38 \\
\hline & 6.56 & 0.113 & 3.963 & 2.06 & 1.695 \\
\hline \multirow{3}{*}{ 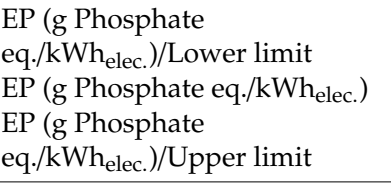 } & 0.15 & $5.94 \times 10^{-3}$ & 0.308 & 0.161 & 0.135 \\
\hline & 0.19 & 0.01 & 0.38 & 0.2 & 0.16 \\
\hline & 0.23 & $9.28 \times 10^{-3}$ & 0.472 & 0.252 & 0.207 \\
\hline \multirow{3}{*}{ 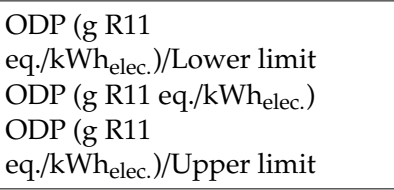 } & $2.21 \times 10^{-13}$ & $7.82 \times 10^{-11}$ & $1.38 \times 10^{-10}$ & $9.94 \times 10^{-12}$ & $6.54 \times 10^{-11}$ \\
\hline & $2.74 \times 10^{-13}$ & $1.02 \times 10^{-10}$ & $1.73 \times 10^{-10}$ & $1.23 \times 10^{-11}$ & $8.19 \times 10^{-11}$ \\
\hline & $3.38 \times 10^{-13}$ & $1.20 \times 10^{-10}$ & $2.17 \times 10^{-10}$ & $1.50 \times 10^{-11}$ & $1.03 \times 10^{-10}$ \\
\hline \multirow{3}{*}{$\begin{array}{l}\text { HTP (g DCB } \\
\text { eq./kWh } \text { elec. }_{\text {eq }} / \text { Lower limit } \\
\text { HTP (g DCB eq./kWh } \text { elec. }) \\
\text { HTP (g DCB } \\
\left.\text { eq./kWh } h_{\text {elec. }}\right) / \text { Upper limit }\end{array}$} & 142.69 & 12.12 & 67.61 & 28.79 & 30.52 \\
\hline & 177.00 & 15.2 & 83.9 & 35.60 & 37.90 \\
\hline & 217.89 & 19.00 & 104.12 & 43.95 & 47 \\
\hline $\begin{array}{l}\mathrm{ADP}_{\text {fossils }}(\mathrm{MJ} / \mathrm{kWh} \text { elec. }) / \text { Lower } \\
\text { limit }\end{array}$ & 6.04 & 0.217 & 0.477 & 0.163 & 0.252 \\
\hline $\mathrm{ADP}_{\text {fossils }}\left(\mathrm{MJ} / \mathrm{kWh}_{\text {elec. }}\right)$ & 7.46 & 0.27 & 0.60 & 0.2 & 0.31 \\
\hline $\begin{array}{l}\mathrm{ADP}_{\text {fossils }}\left(\mathrm{MJ} / \mathrm{kWh}_{\text {elec. }}\right) / \mathrm{Upper} \\
\text { limit }\end{array}$ & 9.22 & 0.34 & 0.743 & 0.249 & 0.391 \\
\hline
\end{tabular}




\section{Conclusions}

This paper offered in much detail, the environmental impact of integrating renewable energy systems to grid-mix in the northern part of Nigeria. This begins with the conventional generation system case, taking the country's BAU path as a grid-only power to renewable energy integration on the basis of the obtained result of the techno-economic optimization exercise conducted with HOMER software. Different scenarios in hybrid were considered with different assumptions made, and balances evaluations on the baseline HOMER result input data to the life cycle assessment. Different data sets for the African continent were applied of the different renewable energy as well as the conventional energy processes applicable to the systems modelling. Simulations were done with the impact categories and elementary mass balances all obtained using the GaBi software. Lastly, an uncertainty analysis was conducted on the impact data based on the pedigree matrix and Excel program as well as a wrap-up policy relevance discussion. It is noted that the whole scenarios where scaled down to a functional unit of $1 \mathrm{kWh}$ as the electricity reference flow for the comparison.

Regarding the elementary mass flow balance, it was observed that the third scenario had the highest contributions in output indicators, namely aggregate deposited goods, aggregate emissions to air, aggregate emissions to seawater, aggregate emissions to agricultural soil, and aggregate emissions to industrial soil. Only one output indicator was observed with first scenario having highest share, which was the aggregate emissions to freshwater.

On the specific environmental impact categories analyzed, it could be said that scenarios in which the considered renewables appeared in the different hybrid configurations that contributed the most on the impacts applied to the ODP, and EP categories. This arises with values obtained majorly during the materials extractions, processing and components fabrication phase of the systems, such as the release of heavy metals, ozone-depleting gases and so on. However, other pollutants and gases emissions aside from the greenhouse gases are also peculiar to the biomass-biogas system in system operations. Notwithstanding, the grid-integration of the renewable energy systems in the case study country on a low carbon development basis, which ensures reduction in the uptake level of fossil fuels, is important for environmental sustainability. This is owing to the outstanding features they offered based on minimization of the GWP, HTP, AP, and ADP impacts from the conventional scenario path. The hybrid system idea in linking the different renewable systems to the grid to allay possible drawbacks on any environmental impact inherent in one is worth doing especially giving preference to the scenarios that appeared with the lowest contributions of all, in some of the impact categories.

Author Contributions: Conceptualization, R.B. and I.A.J.; methodology, I.A.J.; software, I.A.J.; formal analysis, I.A.J.; investigations and data curation, I.A.J.; writing-original draft preparation, I.A.J.; review, corrections and overall supervision, R.B. and A.Z.

Funding: This research was carried out under the project "Water and Energy Security in Africa (WESA-ITT)", that is financially supported through the German Ministry of Education and Research (BMBF) via its project management agency (DLR).

Conflicts of Interest: The authors declare no conflict of interest. 
Nomenclature

\begin{tabular}{|c|c|}
\hline Acronyms and Abbreviations & Units, Symbols and Chemical Formulas \\
\hline AP-Acidification Potential & GWh—Giga Watt Hour \\
\hline ADP_-Abiotic Depletion Potential & kg-Kilogram \\
\hline BACPV_Building Added Concentrated Photovoltaics & kW-Kilo Watt \\
\hline BIPV_Conventional Building Integrated Photovoltaics & Wh-Kilo Watt Hour \\
\hline BAU—Business as Usual & MJ-Mega Joule \\
\hline \multicolumn{2}{|l|}{ BOD—Biochemical Oxygen Demand } \\
\hline COD_Chemical Oxygen Demand & Mol H${ }^{+}$-Mole of Hydrogen Ion \\
\hline CFC-11/R-11-Trichloro Fluoro Methane & $\mathrm{m}^{3}$-Cubic Meters \\
\hline CML_LCIA Method & Yr.-Year \\
\hline \multicolumn{2}{|l|}{ DCB-1,4 Di-chlorobenzene } \\
\hline \multicolumn{2}{|l|}{ DCP-Di-chlorophenol } \\
\hline \multicolumn{2}{|l|}{ Eq.-Equivalence } \\
\hline \multicolumn{2}{|l|}{ EPA-Environmental Protection Agency } \\
\hline EP-Eutrophication Potential & As-Arsenic \\
\hline FAETP_Freshwater Aquatic Ecotoxicity Potentials & $\mathrm{C}$-Carbon \\
\hline FU-Functional Unit & $\mathrm{Ce}-$ Cesium \\
\hline GaBi-Ganzleitlichen Bilanz (Holistic Balance) & $\mathrm{Cd}-\mathrm{Cadmium}$ \\
\hline Ghg-Greenhouse Gases & $\mathrm{Cr}$-Chromium \\
\hline GWP_Global Warming Potential & Fe-Iron \\
\hline HFO_-Heavy Fuel Oil & $\mathrm{H}-$ Hydrogen \\
\hline HOMER_-Hybrid Optimization Model for Electric Renewables & $\mathrm{Hg}$-Mercury \\
\hline HTP_-Human Toxicity Potentials & $\mathrm{Pb}$-Lead \\
\hline ICE-Inventory of Carbon and Energy & $\mathrm{Sb}$-Antimony \\
\hline ISO_-International Standard Organization & TI-Thallium \\
\hline LCA—Life Cycle Assessment & $\mathrm{U}_{235}$-Uranium \\
\hline \multicolumn{2}{|l|}{ LCC_Life Cycle Costing } \\
\hline \multicolumn{2}{|l|}{ LCIA—Life Cycle Impact Assessment } \\
\hline \multicolumn{2}{|l|}{ LCI-Life Cycle Inventory } \\
\hline MAETP_Marine Aquatic Ecotoxicity Potentials & $\mathrm{CO}_{2}-$ Carbon Dioxide \\
\hline N/A-Not Applicable & $\mathrm{CH}_{4}$-Methane \\
\hline NEA-Net Energy Analyses & $\mathrm{HCl}-\mathrm{Hydrogen}$ Chloride \\
\hline NG-Natural Gas & HF-Hydrogen Fluoride \\
\hline ODP—Ozone Layer Depletion Potential & $\mathrm{NH}_{3}$-Ammonia \\
\hline PAF-Potentially Affected Fraction & $\mathrm{N}_{2} \mathrm{O}-$ Nitrous Oxide \\
\hline PM-Particulate Matter & $\mathrm{NO}_{\mathrm{x}}-$ Nitrogen Oxide(s) \\
\hline PV-Photovoltaics & $\mathrm{N}_{2}$-Nitrogen Gas \\
\hline R\&D—Research and Development & $\mathrm{NH}_{4}{ }^{+}$-Ammonium Ion \\
\hline RAF-Data for Africa on Average & $\mathrm{PO}_{4}{ }^{2-}$-Phosphate Ion \\
\hline ReCiPe-LCIA Method & $\mathrm{SO}_{2}-$ Sulfur Dioxide \\
\hline \multicolumn{2}{|l|}{ TETP-Terrestrial Ecotoxicity Potential } \\
\hline \multicolumn{2}{|l|}{ TOC_-Total Organic Carbon } \\
\hline \multicolumn{2}{|l|}{ TRACI_LCIA Method } \\
\hline \multirow{2}{*}{\multicolumn{2}{|c|}{$\begin{array}{l}\text { SIMAPro-System Integrated Environmental Assessment of } \\
\text { Products }\end{array}$}} \\
\hline & \\
\hline VOC_-Volatile Organic Compounds & \\
\hline
\end{tabular}




\section{References}

1. Elliot, J.A. An Introduction to Sustainable Development, 3rd ed.; Routledge Taylor and Francis Group: New York, NY, USA, 2006.

2. Ayodele, T.R.; Ogunjuyigbe, A.S.O.; Alao, M.A. Life cycle assessment of waste-to-energy (WtE) technologies for electricity generation using municipal solid waste in Nigeria. Appl. Energy 2017, 201, 200-218. [CrossRef]

3. Kelly, B. A Life Cycle Assessment of a Diesel Generator Set. Master's Thesis, Digital Commons @ Montana Tech, Montana, MT, USA, 2016.

4. Anoop, S.; Olsen, I.S.; Pant, D. Life Cycle Assessment of Renewable Energy Sources; Springer: Berlin, Germany, 2013; p. 16.

5. Howe, J.; Pepke, E.; Fernholz, K. A Review of Life Cycle Assessment Tools; Dovetail Partners, Inc.: Minneapolis, MN, USA, 2017.

6. Menke, D.M.; Gari, A.D.; Vigon, B.W. Evaluation of Life Cycle Assessment Tools; n.pub; Environment, Canada: Gatineau, QC, Canada, 1996.

7. Bruijn, H.D.; Duin, R.V.; Huijbregts, M.A.; Lindeijer, E. Handbook on Life Cycle Assessment Operational Guide to the ISO Standards; Kluwer Academic Publishers: Dordrecht, The Netherlands, 2002; Volume 7, p. 687.

8. Luo, W.; Khoo, S.Y.; Kumar, A.; Chong Low, S.J.; Li, Y.; Tan, S.Y. A comparative life-cycle assessment of photovoltaic electricity generation in Singapore by multicrystalline silicon technologies. Sol. Energy Mater. Sol. Cells 2018, 174, 157-162. [CrossRef]

9. Li, T.; Roskilly, P.A.; Wang, Y. A Regional Life Cycle Sustainability Assessment Approach and its Application on Solar Photovoltaic. Energy Procedia 2017, 105, 3320-3325. [CrossRef]

10. Liptow, C.; Janssen, M.; Tillman, A.-M. Accounting for effects of carbon flows in LCA of biomass-based products-Exploration and evaluation of a selection of existing methods. Int. J. Life Cycle Assess. 2018, 23, 2110-2125. [CrossRef]

11. Jones, C.; Gilbert, P.; Raugei, M.; Mander, S.; Lecissi, E. An approach to prospective consequential life cycle assessment and net energy analysis of distributed electricity generation. Energy Policy. 2017, 100, 350-358. [CrossRef]

12. Siddiqui, O.; Dincer, I. Comparative Assessment of the Environmental Impacts of Nuclear, Wind and Hydro-Electric Power Plants in Ontario: A Life Cycle Assessment. J. Clean. Prod. 2017, 164, 848-860. [CrossRef]

13. Uddin, S.M.; Kumar, S. Energy, emissions and environmental impact analysis of wind turbine. J. Clean. Prod. 2014, 69, 153-164. [CrossRef]

14. Atilgan, B.; Azapagic, A. Renewable electricity in Turkey: Life cycle environmental impacts. Renew. Energy 2016, 89, 649-657. [CrossRef]

15. Rajput, P.; Singh, K.Y.; Tiwari, G.N.; Sastry, O.S.; Dubey, S.; Pandey, K. Life cycle assessment of the 3.2 kW cadmium telluride (CdTe) photovoltaic system in composite climate of India. Sol. Energy 2018, 159, 415-422. [CrossRef]

16. Santoyo-Castelazo, E.; Azapagic, A. Sustainability assessment of energy systems: Integrating, economic, and social aspects. J. Clean. Prod. 2014, 80, 119-138. [CrossRef]

17. Repele, M.; Bazbauers, G. Life cycle assessment of renewable energy alternatives for replacement of natural gas in building material industry. Energy Procedia 2015, 72, 127-134. [CrossRef]

18. Menoufi, K.; Chemisana, D.; Rosell, J.I. Life cycle assessment of a building added concentrating photovoltaic system (BACPV). Energy Procedia 2017, 128, 194-201. [CrossRef]

19. Ristimaki, M.; Saynajoki, A.; Heinonen, J.; Junnila, S. Combining life cycle costing and life cycle assessment for an analysis of a new residential district energy system design. Energy 2013, 63, 168-179. [CrossRef]

20. Petrillo, A.; Felice, F.D.; Janelli, E.; Autorino, C.; Minutillo, M.; Lavadera, A.L. Life cycle assessment (LCA) and life cycle cost (LCC) analysis model for a stand-alone hybrid renewable energy system. Renew. Energy 2016, 95, 337-355. [CrossRef]

21. Wang, J.; Yang, Y.; Mao, T.; Sui, J.; Jin, H. Life cycle assessment (LCA) optimization of solar-assisted hybrid CCHP system. Appl. Energy 2015, 146, 38-52. [CrossRef]

22. Stephen, I.O.; Egwuonwu, G.; Osazuwa, I. Delineation of All-Season-Recharged Ground Water Reservoir from Two Valleys, Zaria, Nigeria. J. Environ. Hydrol. 2012, 20, 11. 
23. Population.City. Zaria Population. 2015. Available online: http://population.city/nigeria/zaria/ (accessed on 20 November 2017).

24. Samuel, Y. Assessment of Water Quality of Hand-Dug Wells in Zaria LGA of Kaduna State, Nigeria. Int. J. Eng. Sci. 2013, 2, 01-04.

25. National Aeronautics Space Administration (NASA). Surface Meteorology and Solar Energy. Available online: https://eosweb.larc.nasa.gov/sse/RETScreen/ (accessed on 20 October 2017).

26. Biomass Users Network (BUN). Biomass Assessment Hand Book: Bioenergy for a Sustainable Environment; Franl, R., Peter, G., Hemstock, S., Jeremy, W., Eds.; EarthScan: London, UK, 2007.

27. Food and Agricultural Organization (FAO). Crops Data. 2017. Available online: http://www.fao.org/faostat/ en/\#data (accessed on 20 October 2017).

28. United Nations Environmental Program (UNEP). Technologies for Converting Waste Agricultural Biomass to Energy; United Nations Environmental Program (UNEP): Osaka, Japan, 2013.

29. Paul, D.; Nicolae, F.; Matei, F. Main factors affecting biogas production-An overview. Rom. Biotechnol. Lett. J. 2014, 19, 9283-9296.

30. Simonya, K.; Fasina, O. Biomass Resources and Bioenergy Potentials in Nigeria. Afr. J. Agric. Res. 2013, 8, 4975-4989.

31. Moral, R.; Moreno, J.; Perez, M. Characterisation of the organic matter pool in manures. J. Bioresour. Technol. 2004, 96, 153-158. [CrossRef] [PubMed]

32. The Shift Project. Nigerian Electricity Production. Available online: http://www.tsp-dataportal.org/ (accessed on 20 April 2017).

33. Ciroth, A.; Muller, S.; Weidema, B. Empirically based uncertainty factors for the pedigree matrix in ecoinvent. Int. J. Life Cycle Assess. 2016, 21, 1338-1348. [CrossRef]

34. Ecoinvent. Methodology of Ecoinvent 3; Ecoinvent Technoparkstrasse 1: Zurich, Switzerland, 2001; Available online: https://www.ecoinvent.org/support/faqs/methodology-of-ecoinvent-3/how-to-interpretthe-uncertainty-fields-in-ecoinvent.html (accessed on 20 August 2019).

(C) 2019 by the authors. Licensee MDPI, Basel, Switzerland. This article is an open access article distributed under the terms and conditions of the Creative Commons Attribution (CC BY) license (http://creativecommons.org/licenses/by/4.0/). 